\title{
Phospholipid flippases attenuate LPS-induced TLR4 signaling by mediating endocytic retrieval of Toll-like receptor 4
}

\author{
Vincent A. van der Mark $^{1} \cdot$ Mohammed Ghiboub $^{1} \cdot$ Casper Marsman $^{1} \cdot$ Jing Zhao $^{1} \cdot$ \\ Remco van Dijk ${ }^{1} \cdot$ Johan K. Hiralall $^{1} \cdot$ Kam S. Ho-Mok $^{1} \cdot$ Zoë Castricum $^{1}$. \\ Wouter J. de Jonge ${ }^{1} \cdot$ Ronald P. J. Oude Elferink ${ }^{1} \cdot$ Coen C. Paulusma $^{1}$
}

Received: 26 February 2016/Revised: 31 August 2016/Accepted: 6 September 2016/Published online: 14 September 2016 (c) The Author(s) 2016. This article is published with open access at Springerlink.com

\begin{abstract}
P4-ATPases are lipid flippases that catalyze the transport of phospholipids to create membrane phospholipid asymmetry and to initiate the biogenesis of transport vesicles. Here we show, for the first time, that lipid flippases are essential to dampen the inflammatory response and to mediate the endotoxin-induced endocytic retrieval of Toll-like receptor 4 (TLR4) in human macrophages. Depletion of CDC50A, the $\beta$-subunit that is crucial for the activity of multiple P4-ATPases, resulted in endotoxin-induced hypersecretion of proinflammatory cytokines, enhanced MAP kinase signaling and constitutive NF- $\mathrm{BB}$ activation. In addition, CDC50A-depleted THP-1 macrophages displayed reduced tolerance to endotoxin. Moreover, endotoxin-induced internalization of TLR4 was strongly reduced and coincided with impaired endosomal MyD88-independent signaling. The phenotype of CDC50A-depleted cells was also induced by separate knockdown of two P4-ATPases, namely ATP8B1 and ATP11A. We conclude that lipid flippases are novel elements of the innate immune response that are essential to attenuate the inflammatory response, possibly by mediating endotoxin-induced internalization of TLR4.
\end{abstract}

V. A. van der Mark and M. Ghiboub contributed equally.

Electronic supplementary material The online version of this article (doi:10.1007/s00018-016-2360-5) contains supplementary material, which is available to authorized users.

Coen C. Paulusma

c.c.paulusma@amc.uva.nl

1 Tytgat Institute for Liver and Intestinal Research, Academic Medical Center, Meibergdreef 69-71, 1105 BK Amsterdam, The Netherlands
Keywords P4-ATPase - Phospholipid flippase ·

ATP8B1 · Endocytosis · Innate immunity · Macrophage

\section{Introduction}

Toll-like receptor 4 (TLR4) is expressed on myeloidderived cells, including macrophages and dendritic cells, and on some epithelial and endothelial cells and is an essential component of the innate immune response [1]. Activation of TLR4 involves multiple co-receptors, including lipopolysaccharide-binding protein, myeloid differentiation protein 2 and CD14. These co-receptors mediate ligation and transfer of lipopolysaccharides (LPS), an inflammatory mediator of the cell wall of Gram-negative bacteria, to TLR4 [2]. This ligation induces dimerization of TLR4 and activates a MyD88-dependent early response signaling pathway that results in the production of pro-inflammatory cytokines such as TNF $\alpha$, IL$1 \beta$ and IL-6 [3]. Consequently, TLR4 is endocytosed, which induces MyD88-independent signaling from the TLR4-containing endosomal recycling compartment [4-6], inflicting a type I interferon response that is critical to counter an ongoing infection [7]. Importantly, TLR4 internalization reduces signaling from the plasma membrane and dampens the inflammatory reaction. Failure to curtail the TLR4-mediated immune response can lead to pervasive tissue injury and may give rise to immunopathology such as sepsis, autoimmune diseases, metabolic diseases, neurodegeneration and chronic inflammation [1, 8]. Although the molecular mechanisms underlying the endocytic retrieval of TLR4 are poorly understood, it is a dynamin-driven process that strongly depends on CD14 [5, 9]. 
P4-ATPases are a family of phospholipid flippases, i.e., integral membrane proteins that translocate phospholipids from the exoplasmic leaflet to the cytoplasmic leaflet of biological membranes [10-12]. Emerging evidence in $S$. cerevisiae, C. elegans, A. thaliana and mammalian cells indicate important functions for members of the P4ATPase protein family in the biogenesis of intracellular transport vesicles in the biosynthetic and endocytic pathways [10, 13]. For instance, yeast cells deficient for the P4ATPase Drs2p have a defect in the biogenesis of clathrincoated vesicles at the trans-Golgi network (TGN), while combined deficiency of different P4-ATPases leads to defects in fluid-phase endocytosis and intracellular protein transport [14-16]. Similarly, P4-ATPases in C. elegans have been implicated in receptor-mediated and fluid-phase endocytosis and in endocytic sorting and recycling $[17,18]$, while in the plant A. thaliana, P4-ATPases are involved in generation of a specific class of TGN-derived secretory vesicles important for root development [19]. In mammalian cells P4-ATPases probably also fulfill important roles in vesicle biogenesis, but evidence for this is much more scarce. For instance, ATP11B is thought to confer resistance to cis-platinum in ovarian cancer via the biogenesis of cisplatin-containing vesicles at the TGN [20]. ATP8B1 mediates the apical targeting of the apical sodium-dependent bile acid transporter SLC10A2/ASBT, either directly from the TGN or via recycling from a subapical vesicle pool in intestinal Caco-2 cells [21]. Recently, ATP8A1 and ATP8A2 were shown to be essential for membrane fission of recycling endosomes [22].

Thus far, deficiency of two P4-ATPases were shown to cause severe hereditary disease. Mutations in ATP8B1 cause progressive familial intrahepatic cholestasis type 1 , a severe liver disease characterized by impaired bile formation [23]. Mutations in ATP8A2 are associated with a severe neurological disorder described as cerebellar axatia, mental retardation and dysequilibrium syndrome (CAMRQ) [24].

Most P4-ATPases function as a heterodimer with a member of the CDC50 protein family, in which the P4 ATPase is the $\alpha$-subunit and CDC50 the $\beta$-subunit $[11,25]$. The human genome encodes fourteen P4-ATPases and three CDC50 proteins, eleven of which form a heterodimer with CDC50A. CDC50A is a $\sim 50-\mathrm{kDa}$ complex-glycosylated transmembrane protein [26], and its interaction with individual P4-ATPases is essential for endoplasmic reticulum exit and activity of the heterodimer [27-30].

Here we have investigated the hypothesis that lipid flippases of the P4-ATPase family are important mediators of TLR4-mediated signaling. We have analyzed the inflammatory reaction of CDC50A-depleted THP-1 and primary human monocyte-derived macrophages upon LPS challenge. Our data point to important functions for multiple P4-ATPases in attenuating TLR4-mediated signaling.

\section{Materials and methods}

\section{Cell culture and lentiviral transduction}

The human monocytic leukemia cell line THP-1 was cultured in RPMI 1640 medium (Gibco) supplemented with $10 \%$ fetal bovine serum (FBS) (Lonza), 2 mM L-glutamine (Lonza), $100 \mathrm{U} / \mathrm{ml}$ penicillin (Lonza), and $100 \mathrm{U} / \mathrm{ml}$ streptomycin (Lonza) at $37{ }^{\circ} \mathrm{C}$ in a $5 \% \mathrm{CO}_{2}$ humidified atmosphere. Knockdown cell lines for CDC50A and P4 ATPases were generated by lentiviral transduction of undifferentiated THP-1 cells [31]. Briefly, $0.5 \times 10^{6}$ cells were incubated with viruscontaining supernatants/RPMI 1640 (1:1) supplemented with $10 \mu \mathrm{g} / \mathrm{ml}$ diethylaminoethyldextran for $4 \mathrm{~h}$. Two days posttransduction, cells were selected with $2 \mu \mathrm{g} / \mathrm{ml}$ puromycin. Validated short-hairpin RNA (shRNA) vectors to CDC50A [TRCN0000159317 (4) and TRCN0000160267 (1)], ATP8B1 (TRCN0000050127) and ATP11A (TRCN0000051887) were obtained through the MISSION shRNA library (SigmaAldrich). SHC002 was included as a control.

Lentiviral constructs to haemagglutinin antigen (HA)tagged CDC50A (HA-CDC50A) and enhanced green fluorescent protein (eGFP)-tagged ATP8B1 (ATP8B1-eGFP) were described previously [27]. A Rab11-eGFP plasmid [32] was AgeI/XbaI-digested and subcloned into a second generation lentiviral transfer vector [31]. ATP11A cDNA was obtained from the PlasmID Repository/DF/HCC DNA Resource Core (http://plasmid.med.harvard.edu). A FLAGtag was introduced on the $3^{\prime}$ end by PCR using forward oligo $5^{\prime}$-cattagctacgaccggtatggactgcagcctcgtgcggacg- $3^{\prime}$ and reverse oligo $5^{\prime}$-ggctggtctagactaCTTGTCATCGTCGT CCTTGTAGTCgaaactcaggctgctggaag- $3^{\prime}$, in which the FLAG sequence is capitalized. All experiments were performed on THP-1 cells differentiated to macrophages with $100 \mathrm{nM}$ phorbol-12-myristate-13-acetate (PMA) (SigmaAldrich) for 3 days, after which they were rested for 2-3 days in PMA-free culture medium [33]. Differentiated THP-1 cells were challenged with LPS from Escherichia coli 0111:B4 (Sigma-Aldrich) at $37{ }^{\circ} \mathrm{C}, 5 \% \mathrm{CO}_{2}$ for indicated time-points and at indicated concentrations.

\section{Isolation, maturation, polarization and siRNA transfection of monocyte-derived macrophages}

Peripheral blood mononuclear cells (PBMCs) were obtained from whole blood of healthy donors by density gradient centrifugation using Ficoll (Invitrogen). Briefly, $13 \mathrm{ml}$ Ficoll was added below $30 \mathrm{ml}$ PBS-diluted blood 
and centrifuged at $2000 \mathrm{rpm}$ for $20 \mathrm{~min}$ at room temperature, with acceleration 3 and no break. The interphase was recovered using a Pasteur pipet into a new $50 \mathrm{ml}$ tube containing $10 \mathrm{ml}$ PBS, followed by twice washing with PBS. $5 \times 10^{6}$ of PBMCs (containing $\sim 0.5 \times 10^{6}$ monocytes) were incubated in 12-well plates in $1 \mathrm{ml}$ Isocove's Modified Dulbecco's Medium (Lonza) supplemented with $10 \%$ fetal bovine serum (FBS) (Lonza), $2 \mathrm{mM} \mathrm{L-glu-}$ tamine (Lonza), $100 \mathrm{U} / \mathrm{ml}$ penicillin (Lonza) and $100 \mathrm{U} / \mathrm{ml}$ streptomycin (Lonza) for $90 \mathrm{~min}$ at $37{ }^{\circ} \mathrm{C}, 5 \% \mathrm{CO}_{2}$. After $2 \mathrm{~h}$, medium was aspirated and the cells were washed several times with sterilized warm PBS till removing all floating cells. Monocytes were matured using $72 \mathrm{~h}$ treatment with $20 \mathrm{ng} / \mathrm{ml}$ of macrophage colony-stimulating factor (M-CSF). The cells were then washed with PBS and stimulated with $100 \mathrm{ng} / \mathrm{ml} \mathrm{IFN} \gamma$ or $40 \mathrm{ng} / \mathrm{ml} \mathrm{IL-4}$ for 3 days to generate M1 or M2 macrophages, respectively. Medium was added to maturated monocytes (M0 macrophages) for 3 days to keep it as M0 subset. M1 macrophages were transfected using DharmaFECT $^{\mathrm{TM}}$ transfection reagents (Dharmacon) according to the manufacturer's instructions with siGENOME human TMEM30A smartpool siRNAs to deplete CDC50A and non-targeting siRNAs as a control. Cells were analyzed at $72 \mathrm{~h}$ post-transfection.

\section{Enzyme linked immuno sorbent assay}

ELISA (R\&D Systems) for human TNF $\alpha$, IL1 $\beta$ and IL6 were performed according to the manufacturer's instructions.

\section{Quantitative RT-PCR}

Total RNA was isolated from differentiated cells using TriPURE reagent (Invitrogen). cDNA was synthesized from $2 \mu \mathrm{g}$ of total RNA with random hexamers and oligo dT 12-18 primer and Superscript III RT (Invitrogen). Realtime PCR measurements were performed on a Lightcycler 480 (Roche) with Fast Start DNA MasterPlus SYBR Green I kit (Roche). Expression levels in THP-1 cells and human monocyte-derived M1 macrophages were calculated with the LinregPCR software [34] and were normalized to the geometric means of the three most stable reference genes (RPLP0, ACTB, GAPDH) as determined by Genorm analysis [35]. Expression levels in primary mouse cells were calculated similarly and were normalized to Rplp0. Primer sequences are depicted in supplemental Table 1.

\section{Isolation of nuclear extracts}

Cells were washed with ice-cold PBS, scraped into solution and pelleted by centrifugation $(400 \times g, 10 \mathrm{~min}$, $\left.4{ }^{\circ} \mathrm{C}\right)$. The cell pellet was washed in 5 packed cell volumes (PCV) resuspension buffer (10 mM HEPES pH 7.9, $1.5 \mathrm{mM} \mathrm{MgCl}_{2}, 10 \mathrm{mM} \mathrm{KCl}, 0.5 \mathrm{mM}$ DTT) supplemented with $0.5 \mathrm{mM}$ phenylmethanesulfonylfluoride, phosSTOP phosphatase and protease inhibitor cocktails (Roche) and centrifuged $\left(400 \times g, 10 \mathrm{~min}, 4{ }^{\circ} \mathrm{C}\right)$. The cell pellet was incubated for $10 \mathrm{~min}$ on ice in $2 \mathrm{PCV}$ resuspension buffer and homogenized with a Dounce homogenizer (tight pestle, 60 strokes). Cell lysis was confirmed via microscopic analysis and non-broken cells were pelleted by centrifugation $\left(200 \times g, 2 \mathrm{~min}, 4^{\circ} \mathrm{C}\right)$. The resulting supernatant was pelleted again by centrifugation $\left(425 \times g, 10 \mathrm{~min}, \quad 4^{\circ} \mathrm{C}\right)$. The supernatant containing the cytosolic fraction was stored on ice and the nuclei-containing pellet was resuspendend in ultracentrifuge resuspension buffer $(20 \mathrm{mM}$ HEPES $\mathrm{pH}$ 7.9, $1.5 \mathrm{mM} \mathrm{MgCl}_{2}, 0.42 \mathrm{M} \mathrm{NaCl}, 0.5 \mathrm{mM}$ DTT, $0.2 \mathrm{mM}$ EDTA, $25 \%$ v/v glycerol, $0.5 \mathrm{mM}$ phenylmethanesulfonylfluoride, phosSTOP phosphatase and protease inhibitor cocktails) and incubated while rotating for $30 \mathrm{~min}$ at $4{ }^{\circ} \mathrm{C}$. The nuclear and cytosolic fractions were each separately subjected to ultracentrifugation in an Optima L-90K ultracentrifuge (Beckton Dickenson, Ti70 rotor, $32,000 \times g, 30 \mathrm{~min}, 4{ }^{\circ} \mathrm{C}$ ). Cleared supernatants were stored at $-80{ }^{\circ} \mathrm{C}$ until use.

\section{SDS-PAGE and western blotting}

Cells were lysed in RIPA buffer (50 mM Tris-HCl, pH 8.0, $150 \mathrm{mM} \mathrm{NaCl}, 1 \% \mathrm{NP}-40,0.5 \%$ Na-deoxycholate, $0.1 \%$ SDS) containing protease inhibitor cocktail (Roche) and/or PhosSTOP phosphatase inhibitor cocktail (Roche). Proteins were separated on a polyacrylamide gel (6-12\% depending on the size of the protein of interest) and were transferred to Immobilon-P PVDF membranes (Millipore) by semi-dry blotting using $10 \mathrm{mM}$ CAPS, pH 10.5/15\% methanol buffer. Membranes were blocked for $1 \mathrm{~h}$ at RT in block buffer [PBS/5 \% low-fat milk (Nutricia Profitarplus)] and incubated for $1 \mathrm{~h}$ at RT in block buffer with rabbit polyclonal antibodies to TLR4 (H-80, Santa Cruz), CDC50A [26], ATP8B1 [36], histone H3 [(di methyl K79) antibody-ChIP Grade (Abcam)], ATP1A1 [37], phosphoSAPK/JNK (Thr183/Tyr185), SAPK/JNK, phospho-p44/42 MAPK (Erk1/2) (Thr202/Tyr204), p44/42 MAPK (Erk1/2), mouse monoclonal to phospho-NF-kB p65 (Ser536) (7F1) (all from Cell Signaling), NF- $\kappa \mathrm{B}$ p65 (F-6) (Santa Cruz), GAPDH (MAB374, Millipore), and $\beta$-actin (clone AC-15, Sigma Aldrich). Immune complexes were visualized with peroxidase-conjugated goat-anti-rabbit or mouse IgGs (Bio-Rad), developed with homemade enhanced chemiluminescence reagents (100 mM Tris- $\mathrm{HCl}, \mathrm{pH} 8.5,1.25 \mathrm{mM}$ luminol, $0.2 \mathrm{mM}$-coumarin and freshly added $3 \mathrm{mM}$ $\mathrm{H}_{2} \mathrm{O}_{2}$ ) and detected using an ImageQuant ${ }^{\mathrm{TM}}$ LAS 4000 
(GE Healthcare). Densitometric analyses of band intensities were performed using ImageJ 1.49.

\section{Indirect immunofluorescence}

Differentiated THP-1 cells (knockdowns, HA-CDC50A/ Rab11eGFP-, ATP8B1eGFP- and ATP11A-Flag over-expressing) were grown on glass coverslips and fixed in $2 \%$ paraformaldehyde (PFA) for $20 \mathrm{~min}$ at RT. PFA fixed cells were permeabilized on PBS/0.1\% triton X-100 (PBS-Tx) and incubated with rat monoclonal anti-HA (clone 3F10; Roche) to detect CDC50A, mouse monoclonal anti-Flag (M2, Sigma) to detect ATP11A or rabbit polyclonal antiTLR4 (H-80, Santa Cruz). Cells were extensively washed in between antibody incubations in PBS-Tx. Immunoreactivity was visualized with goat-anti-rat Texas Red, goatanti-mouse Alexa 488 or goat-ant-rabbit Alexa 594 (Molecular Probes). Sections were mounted in Vectashield/ DAPI (Vector Laboratories) and were imaged on a SP8-XSMD confocal microscope (Leica) or on a DMi8 microscope (Leica).

\section{Measuring TLR4/CD14/CD11B surface expression by flow cytometry}

PMA-differentiated THP-1 cells $\left(2 \times 10^{6} /\right.$ well, 6-well plate) were washed with ice-cold PBS and were incubated in ice-cold PBS containing $5 \mathrm{mM}$ ethylenediaminetetraacetic acid (PBS/EDTA) for $10 \mathrm{~min}$ on ice. Cells were removed using a cell scraper (Corning) and were transferred to eppendorf tubes. Cells were centrifuged for $5 \mathrm{~min}$ at $240 \times g$ and supernatant was removed after which the cell pellet was incubated with mouse IgG2a phycoerythrin (PE)-conjugated anti-human CD284 (TLR4) antibody (clone HTA125, BioLegend, San Diego, USA), mouse IgG2b PE-conjugated anti-human CD14 (clone M $\phi$ P9, BD Biosciences) or mouse IgG1 Alexa Fluor 488-conjugated anti-human CD11B (clone ICRF44, BD Biosciences) in PBS for $45 \mathrm{~min}$ at $4{ }^{\circ} \mathrm{C}$ in the dark with constant agitation. Subsequently cells were washed with ice-cold PBS, were resuspended in PBS and immediately analyzed by flow cytometry using a BD LSRFortessa ${ }^{\mathrm{TM}}$ cell analyzer (BD Biosciences). To analyze LPS-induced TLR4/CD14 internalization, differentiated THP-1 cells and human monocyte-derived M1 macrophages were challenged with LPS (concentration indicated in figure legend) at $37{ }^{\circ} \mathrm{C}$, $5 \% \mathrm{CO}_{2}$ for indicated time-points. Cells were analyzed as described above.

\section{Statistics}

Data are displayed as mean \pm standard deviation (sd) or standard error of the mean (sem). Statistical significance was determined by performing Student's $t$ test or one-way ANOVA with Bonferroni's correction for multiple testing as indicated in the legend of the figures.

\section{Results}

\section{CDC50A is required to dampen the inflammatory reaction triggered by LPS in human macrophages}

To investigate the role of CDC50A-interacting P4-ATPases in the innate immune response in macrophages, we analyzed the inflammatory response to LPS challenge in human THP-1 and primary human monocyte-derived macrophages (MDMs) that were depleted from CDC50A. As we could not localize endogenous CDC50A, we assessed the localization of ectopically expressed HA-tagged CDC50A in differentiated THP-1 macrophages (Fig. 1a). HA-CDC50A localized to intracellular vesicles and almost complete costained with Rab11, a marker for recycling endosomes and the endocytic recycling compartment; in addition, weak plasma membrane staining was detected. Since CDC50A is only released from the endoplasmic reticulum in association with a P4-ATPase [28], this localization most likely represents a functional CDC50A-P4-ATPase association. Stable CDC50A-depleted THP-1 cells (further referred to as CDC50A.4 cells) were generated by constitutive expression of short hairpin RNA sequences targeting CDC50A. CDC50A mRNA expression was reduced by $>80 \%$ in CDC50A.4 cells compared to shControl cells (Fig. 1b), which coincided with strongly reduced CDC50A protein levels (Fig. 1c). CDC50A depletion did not interfere with cell growth, morphology or differentiation, the latter evidenced by normal CD11B surface expression (supplementary figure 1A). Differentiated THP-1 cells were incubated for $4 \mathrm{~h}$ with LPS and TNF $\alpha$, IL-1 $\beta$ and IL6 secretion was quantified by ELISA. Compared to shControl cells, CDC50A.4 macrophages showed a strongly enhanced output ( $>6$ fold) of TNF $\alpha$, IL-1 $\beta$ and IL6 upon LPS challenge (Fig. 1d). This phenotype was reproduced in CDC50A-depleted THP-1 cells generated by a different shRNA sequence (supplementary figure 1B). The enhanced secretion of these cytokines was mirrored by their mRNA expression (Fig. 1e).

To verify the physiological relevance of the hyper-inflammatory phenotype observed in CDC50A-depleted THP-1 cells, we performed the same analyses in primary human MDMs in which CDC50A was transiently depleted by CDC50A-directed siRNA transfection. Analyses were performed in M1 polarized MDMs, M1 polarization evidenced by high expression of M1-specific marker CD80 and absence of M2-specific marker CD200R (supplemental 
a
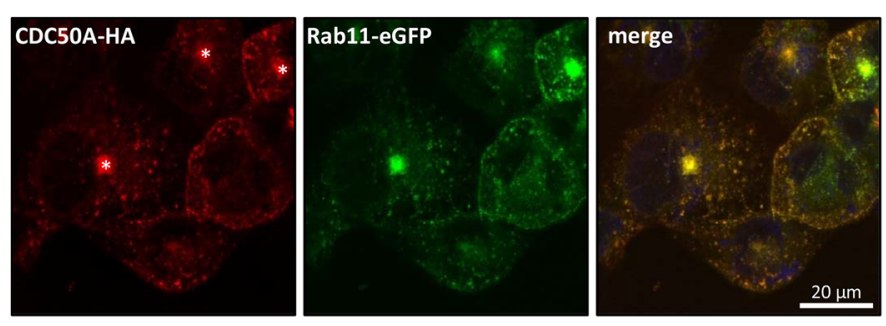

d

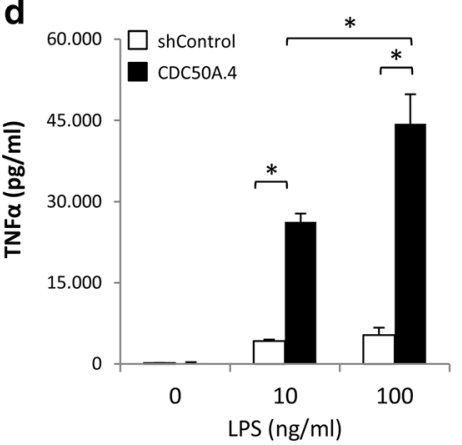

e

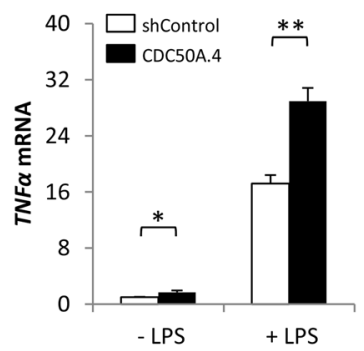

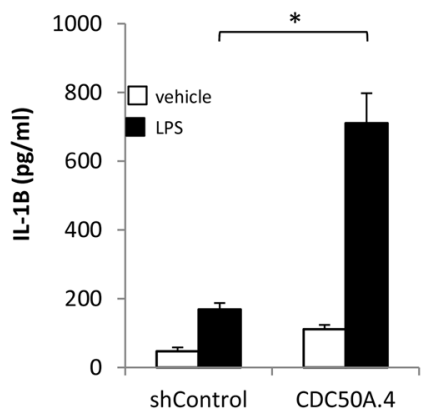

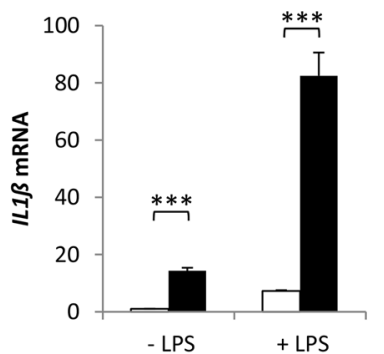

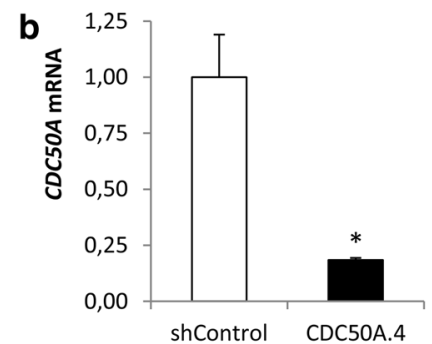

C

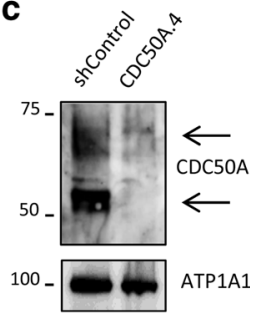

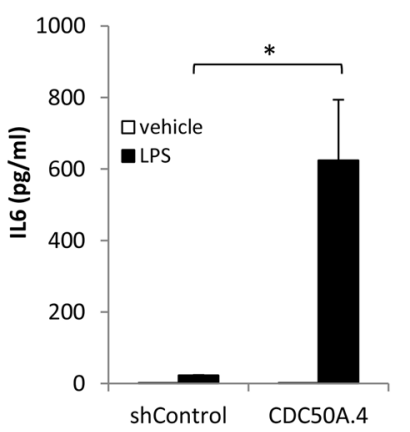

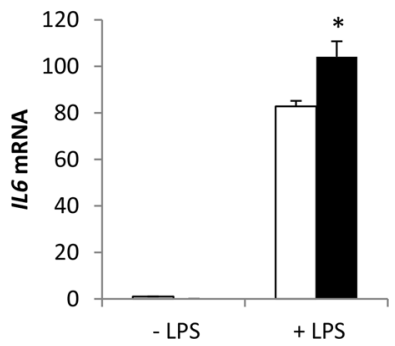

Fig. 1 CDC50A depletion leads to endotoxin-induced hypersecretion of inflammatory cytokines in THP-1 macrophages. a Confocal microscopical detection of HA-tagged CDC50A and GFP-tagged Rab11 in THP-1 macrophages. CDC50-HA co-stained with Rab11eGFP-positive (recycling) endosomes and the endocytic recycling compartment (indicated by an asterisk in merge). Nuclear DAPI staining in blue. b CDC50A mRNA levels in shControl and CDC50Adepleted THP-1 macrophages. Data shown are mean \pm standard deviation of triplicate wells. mRNA expression in shControl cells was set as 1. Statistical significance was tested by a Student's $t$ test, $* p<0.002$. c Immunoblot analysis of CDC50A protein levels in membrane isolates of shControl and CDC50A-depleted THP-1 macrophages. Arrows indicate the different glycosylation states of

figure 1C) [38]. 72 Hour post-transfection MDMs were challenged for $4 \mathrm{~h}$ with LPS and the inflammatory response was assessed (Fig. 2). CDC50A mRNA expression and protein levels were strongly reduced $72 \mathrm{~h}$ post-transfection (Fig. 2a, b). In contrast to CDC50A-depleted THP-1 macrophages, CDC50A-depleted M1 macrophages displayed no elevated excretion of TNFa; However, IL6 and IL10 excretion was $\sim 6$ fold increased by these cells, while IL1 $\beta$ tended to be increased (Fig. 2c). Also at the mRNA level, expression of most of mentioned cytokines was slightly elevated (Fig. 2d). Collectively these data suggest that CDC50A-associated P4-ATPases negatively regulate TLR4-mediated signaling in human macrophages.

CDC50A. ATP1A1 is included as a loading control. d TNF $\alpha$, IL1- $\beta$ and IL6 secretion in shControl and CDC50A-depleted THP-1 macrophages $4 \mathrm{~h}$ after $100 \mathrm{ng} / \mathrm{ml}$ LPS administration. Data shown are mean \pm standard deviation of quadruple wells. Statistical significance was tested by one-way ANOVA with Bonferroni's correction for multiple testing, ${ }^{*} p<0.005$. e $T N F \alpha, I L-1 \beta$ and IL6 mRNA expression levels in shControl and CDC50A-depleted THP-1 macrophages $3 \mathrm{~h}$ post-LPS administration. Data shown are mean \pm standard deviation of triplicate wells. mRNA expression in shControl cells without LPS was set as 1 . Statistical significance was tested by a Student's $t$ test, ${ }^{*} p<0.05,{ }^{* *} p<0.001,{ }^{* *} p<0.0001$. Data shown in this figure are representative of three to six independent experiments with similar results

\section{CDC50A attenuates TLR4-mediated signaling in human macrophages}

TLR4 activation by LPS leads to induction of the interferon signaling pathway from TLR4-containing endosomes $[5,6]$. This late response is characterized by the induction of interferon $\beta($ IFN $\beta)$ and RANTES/CCL5, which we analyzed in CDC50A-depleted THP-1 and primary MDMderived macrophages (Fig. 3). In both control and CDC50A-depleted macrophages LPS challenge induced IFN $\beta$ and RANTES, however, the induction was significantly less in CDC50A-depleted THP-1 (Fig. 3a) and MDMs (Fig. 3b). Similarly, suppressor of cytokine 
a

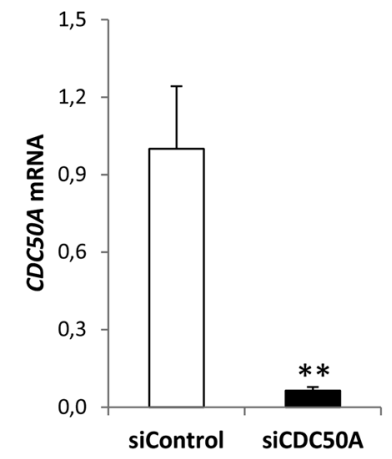

C

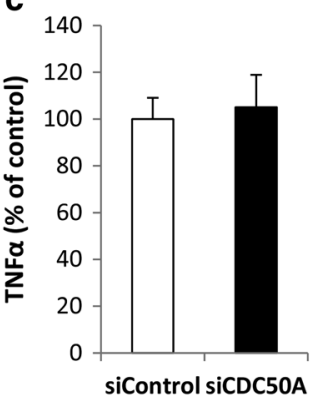

d

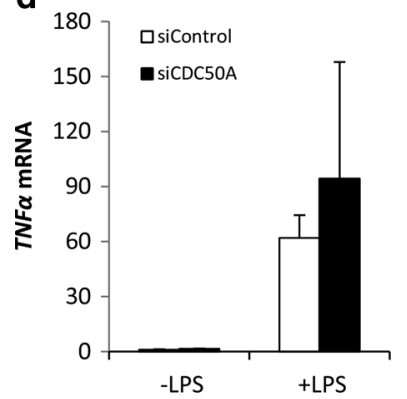

b

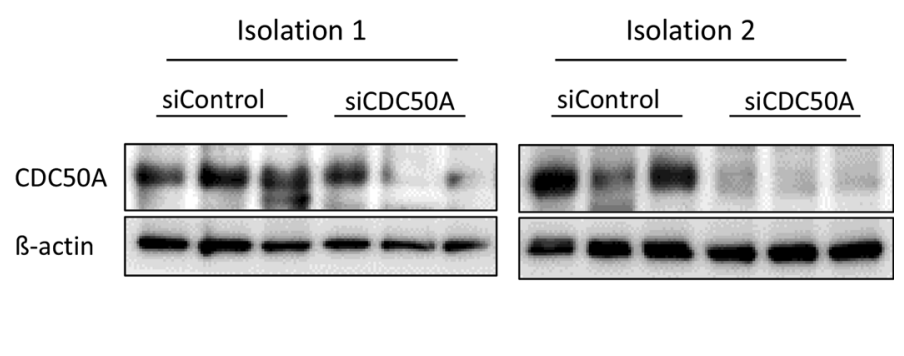

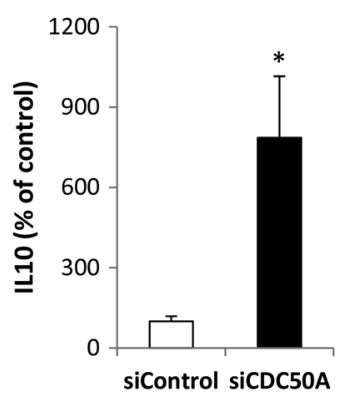

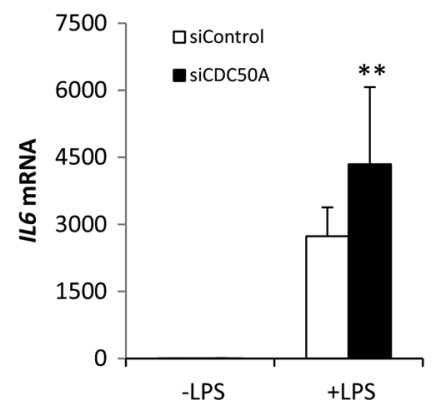

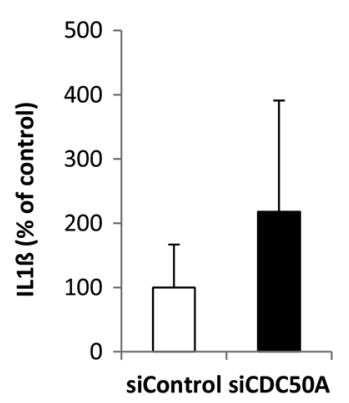

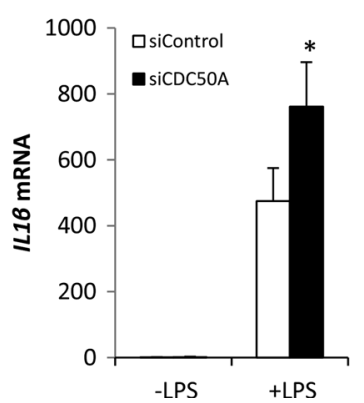

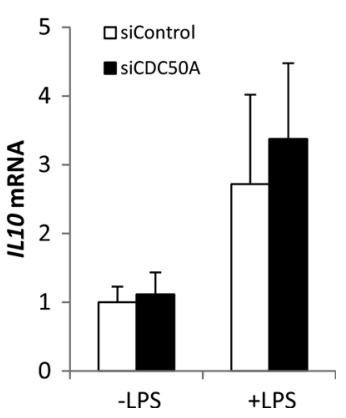

Fig. 2 CDC50A depletion leads to endotoxin-induced hypersecretion of inflammatory cytokines in primary human monocyte-derived macrophages. a CDC50A mRNA levels in primary human monocyte-derived macrophages (MDM) transfected with scrambled siRNAs (siControl) and siRNAs directed to CDC50A (siCDC50A). RNA was isolated 72-h post-transfection. Data shown are mean \pm standard deviation; $n=8$ of two different isolations. Statistical significance was tested by a Student's $t$ test, $* * p<0.0005$. b Immunoblot analysis of CDC50A protein levels in total lysates of two independent isolations of MDMs. $\beta$-Actin is included as a loading control. c TNF $\alpha$, IL6, IL1- $\beta$ and IL10 secretion in siControl and

signaling 1 (SOCS1), which is a negative regulator of TLRmediated signaling to dampen the inflammatory reaction [39], was induced in LPS-challenged macrophages, however, this induction was significantly reduced in CDC50Adepleted THP-1 and MDMs, suggesting impaired negative feedback regulation of TLR4-mediated signaling (Fig. 3a, b). These data suggest that CDC50A plays an important role in the induction of the interferon response and in dampening the TLR4-mediated inflammatory reaction in macrophages. Since in both CDC50A-depleted THP-1 and primary human macrophages downstream signaling of

siCDC50A MDMs (72 $\mathrm{h}$ post-transfection) that were stimulated for $4 \mathrm{~h}$ with $100 \mathrm{ng} / \mathrm{ml}$ LPS. Data shown are mean \pm SEM of $n=10$ of four different isolations. Statistical significance was tested by a Student's $t$ test, $* p<0.05$ (d) $T N F \alpha, I L 6, I L-1 \beta$ and IL10 mRNA expression levels in siControl and siCDC50A MDMs (72 h posttransfection) $3 \mathrm{~h}$ post-LPS $(100 \mathrm{ng} / \mathrm{ml})$ administration. Data shown are mean \pm standard deviation ( $n=8,2$ different isolations). mRNA expression in siControl cells without LPS was set as 1 . Statistical significance was tested one-way ANOVA with Bonferroni's correction for multiple testing, $* p<0.01 ; * * p<0.005$

TLR4 was affected, we further assessed the role of CDC50A in TLR4-mediated signaling in THP-1 macrophages. LPS-induced TLR4 signaling leads to nuclear translocation of the transcription factors AP-1 (via MAPK pathways) and NF- $\kappa \mathrm{B}$ to promote transcription of pro-inflammatory cytokines. We thus analyzed activation (phosphorylation) of c-Jun terminal kinases (JNK) 1/2, extracellular signal-regulated kinases (ERK) $1 / 2$ and NF$\kappa \mathrm{B}$ in LPS challenged cells (Fig. 3c). In CDC50A.4 macrophages JNK phosphorylation was strongly induced already 15 min after LPS challenge and was more sustained 

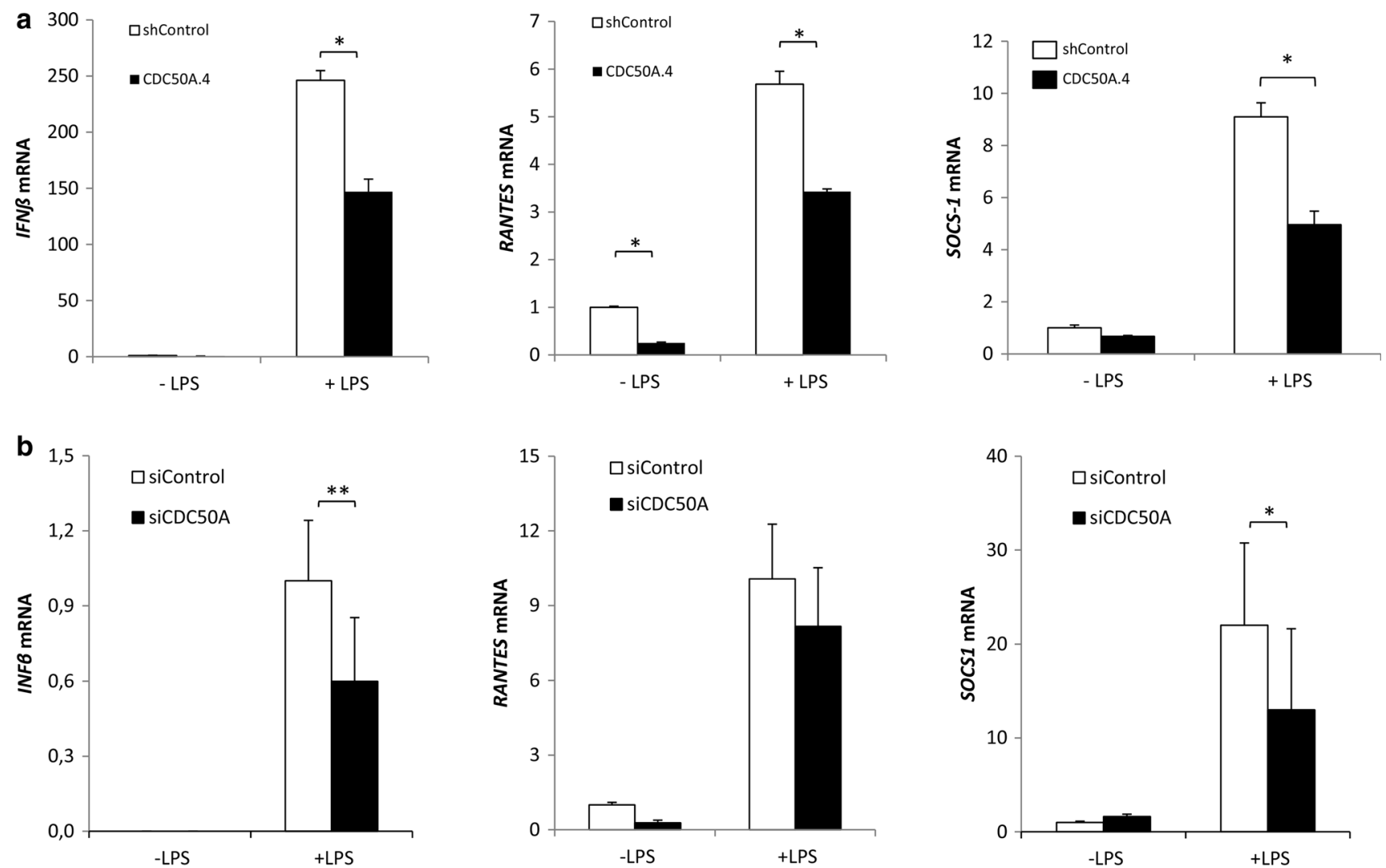

C

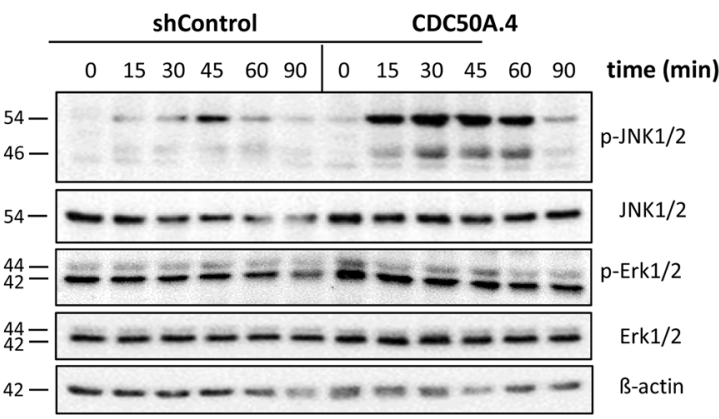

Fig. 3 CDC50A depletion in human macrophages leads to an impaired interferon response and sustained TLR4-mediated signaling. a IFN $\beta$, RANTES and SOCS1 mRNA levels in shControl and CDC50A-depleted THP-1 cells $3 \mathrm{~h}$ post-LPS administration. Data shown are mean \pm standard deviation of triplicate wells. mRNA expression in shControl cells without LPS was set as 1 . Statistical significance was tested by a Student's $t$ test, ${ }^{*} p<0.0005$. Data shown are representative of three to six independent experiments with similar results. b IFN $\beta$, RANTES and SOCS1 mRNA levels in siControl and siCDC50A MDMs (72 h post-transfection) $3 \mathrm{~h}$ postLPS $(100 \mathrm{ng} / \mathrm{ml})$ administration. Data shown are mean \pm standard deviation ( $n=7,2$ different isolations). mRNA expression in

compared to shControl cells. Importantly, the levels of nuclear phosphorylated NF- $\kappa \mathrm{B}$ were strongly increased in both LPS-stimulated and unstimulated CDC50A.4 macrophages (Fig. 3d). These observation provide additional evidence for a role of CDC50A-interacting P4-ATPases in the attenuation of TLR4-mediated signaling. d cytosolic nuclear

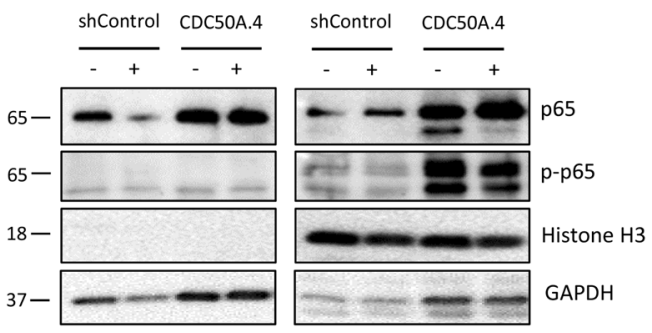

siControl cells without LPS was set as 1 . Statistical significance was tested one-way ANOVA with Bonferroni's correction for multiple testing, $* p<0.05 ; * * p<0.005$. c Immunoblot analysis of activated JNK1/2 and Erk1/2 in shControl and CDC50A-depleted THP-1 macrophages. Cells were incubated with $100 \mathrm{ng} / \mathrm{ml}$ LPS for the time points indicated. $\beta$-Actin is included as a loading control. d Immunoblot analysis of cytosolic and nuclear total and activated NF- $\kappa \mathrm{B}$ p65 in shControl and CDC50A-depleted THP-1 macrophages. Cells were incubated with $10 \mathrm{ng} / \mathrm{ml}$ LPS for $2 \mathrm{~h}$. GAPDH and histone $\mathrm{H} 3$ are included as cytosolic and nuclear loading controls, respectively

\section{CDC50A is required for LPS-induced endocytosis of TLR4 in human macrophages}

The increased and sustained activation of TLR4-dependent signaling in CDC50A-depleted macrophages led us to investigate the surface expression of TLR4 by flow 

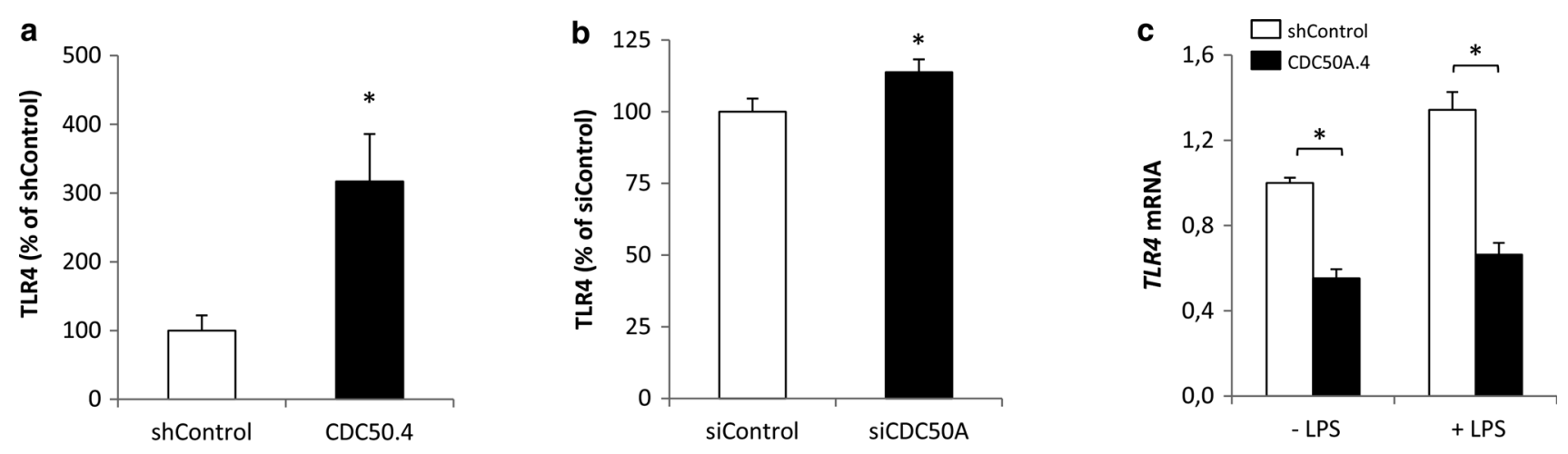

d
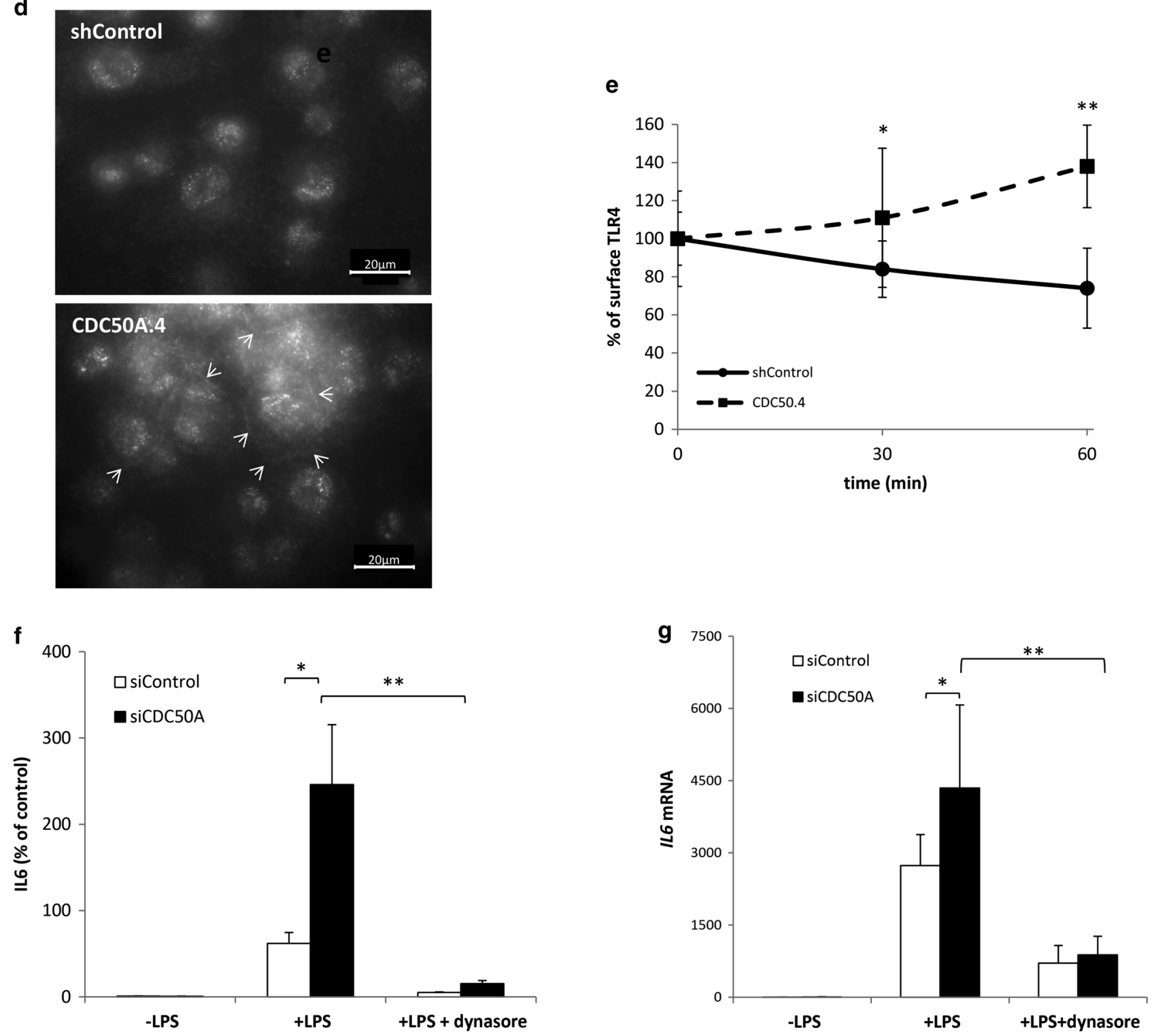
४Fig. 4 CDC50A-depleted THP-1 macrophages are impaired in LPSinduced endocytosis of TLR4. a TLR4 surface expression in shControl and CDC50A-depleted THP-1 macrophages was determined by flow cytometry. Data are expressed as MFI \pm standard deviation of triplicate wells. Statistical significance was tested by a Student's $t$ test, $* p<0.02$. b TLR4 surface expression in siControl and siCDC50A MDMs was determined by flow cytometry. Data are expressed as MFI \pm standard deviation of triplicate wells. Statistical significance was tested by a Student's $t$ test, $* p<0.05$. c TLR4 mRNA levels in shControl and CDC50A-depleted THP-1 cells $3 \mathrm{~h}$ post-LPS administration. Statistical significance was tested by a Student's $t$ test, $* p<0.00005$. d Immunofluorescent detection of TLR4 in shControl and CDC50A.4 cells. Arrows indicate TLR4 staining at the apex of the cells. e TLR4 surface expression in shControl and CDC50A-depleted THP-1 macrophages after stimulation with $100 \mathrm{ng} / \mathrm{ml}$ LPS. Cells were analyzed by flow cytometry. Data shown are MFIs \pm standard deviation at different time points of triplicate wells. Statistical significance was determined between shControl and CDC50A.4 cells and tested by a Student's $t$ test, $* p<0.05, * * p<0.002$. f IL6 secretion in siControl and siCDC50A MDMs (72 h post-transfection) that were stimulated for $4 \mathrm{~h}$ with $100 \mathrm{ng} / \mathrm{ml}$ LPS with/without $80 \mu \mathrm{M}$ dynasore. Dynasore-treated cells were pre-incubated for $30 \mathrm{~min}$ with $80 \mu \mathrm{M}$ dynasore. Data shown are means \pm SEM of $n=8$ of two different isolations. Statistical significance was tested by one-way ANOVA with Bonferroni's correction for multiple testing, $* p<0.005$; $* * p<0.00005$. g IL6 mRNA levels in siControl and siCDC50A MDMs $(72 \mathrm{~h}$ posttransfection) that were stimulated for $4 \mathrm{~h}$ with $100 \mathrm{ng} / \mathrm{ml}$ LPS with/ without $80 \mu \mathrm{M}$ dynasore. Data shown are means \pm standard deviation ( $n=8,2$ different isolations). mRNA expression in siControl cells without LPS was set as 1 . Statistical significance was tested oneway ANOVA with Bonferroni's correction for multiple testing, ${ }^{*} p<0.005 ; * * p<0.0005$. Data shown in this figure are representative of three to four independent experiments with similar results

cytometry. In unstimulated CDC50A-depleted THP-1 and human primary macrophages, we observed a significant 3and 1.2-fold increase, respectively, in surface expression of TLR4 compared to controls (Fig. 4a, b), whereas TLR4 mRNA levels were $\sim 2$ fold decreased only in THP-1 macrophages (Fig. 4c and not shown). The elevated plasma membrane localization of TLR4 was visualized by immunofluorescent staining of TLR4, which outlined the apex of CDC50A.4 cells but not that of shControl cells (Fig. 4d). Previous work has shown that TLR4 is endocytosed upon LPS stimulation, a process that is dependent on CD14 expression [4, 5, 9]. To investigate whether CDC50A was involved in TLR4 endocytosis, we stimulated CDC50A.4 macrophages with LPS and analyzed TLR4 surface expression after 30 and $60 \mathrm{~min}$. While in shControl cells TLR4 surface expression was reduced by $16 \%$ after $30 \mathrm{~min}$ and $26 \%$ after $60 \mathrm{~min}$, TLR4 surface expression was not reduced but increased by $38 \%$ after 60 min in CDC50A.4 macrophages (Fig. 4e). Like TLR4, surface expression of CD14 was twofold increased in CDC50A.4 macrophages, which was mirrored by an increase at the mRNA level, however, no loss of CD14 surface expression was observed in either shControl or
CDC50A.4 macrophages after LPS challenge (supplementary figure 2). These data indicate that CDC50A is essential for LPS-induced endocytosis of TLR4 in macrophages. To verify that the hyperinflammatory reaction of CDC50A-depleted cells was due to impaired TLR4 endocytosis, we chemically blocked TLR4 internalization using the GTPase dynamin inhibitor dynasore [4, 7]. We measured IL6 excretion in CDC50A-depleted human MDMs that were challenged for $4 \mathrm{~h}$ with LPS in the absence and presence of $80 \mu \mathrm{M}$ dynasore. CDC50A-depleted cells displayed strongly elevated IL6 excretion when challenged with LPS alone, however, unexpectedly, dynasore treatment almost completely abolished this effect (Fig. 4f). These observations were mirrored by IL6 mRNA expression levels (Fig. 4g). Collectively these data suggest that, apart from a role in LPS-induced internalization of TLR4, CDC50A-associated P4-ATPases may play a role in the signaling cascade downstream of TLR4.

\section{ATP8B1 and ATP11A-depleted THP-1 macrophages show LPS-induced hypersecretion of pro-inflammatory cytokines}

We analyzed which member(s) of the P4-ATPase family serve(s) as the active $\alpha$-subunit for obligate heterodimerization with CDC50A. To investigate this, we depleted THP-1 cells from all individual P4-ATPases. THP-1 cells expressed 11 P4-ATPases (Fig. 5a), nine of which have been shown to heterodimerize with CDC50A [28-30]. Several P4-ATPase-depleted THP-1 cells displayed poor growth or no survival, still, seven different knockdown lines could be analyzed for the inflammatory reaction to LPS. LPS-induced TNF $\alpha$ excretion was $\sim 2$ - and $\sim 3$-fold elevated only in ATP8B1-depleted cells (ATP8B1.7) and ATP11A-depleted cells (ATP11A.21), respectively, when compared to LPS-induced shControl macrophages (Fig. 5b). Already without LPS stimulation, TNF $\alpha$ output was elevated in both P4-ATPase depleted cells. The enhanced TNF $\alpha$ output was associated with a $\sim 70 \%$ reduction in $A T P 8 B 1$ and $A T P 11 A$ mRNA expression (Fig. 5c). Similar to CDC50A.4 macrophages, ATP8B1.7 and ATP11A.21 macrophages showed an increased and more sustained JNK1/2 phosphorylation already $15 \mathrm{~min}$ after LPS challenge (Fig. 5d). Immunolocalization of ectopically expressed ATP8B1eGFP and ATP11A-Flag showed predominant plasma membrane localization of both proteins (Fig. 5e). Finally, we assessed TLR4 internalization 30 and $60 \mathrm{~min}$ after LPS administration. While after 60 min TLR4 surface expression was reduced by $\sim 50 \%$ in shControl cells, this was $\sim 30 \%$ in ATP8B 1.7 cells, whereas in ATP11A.21 cells no reduction in TLR4 surface expression was observed (Fig. 5f). Both ATP8B1 and ATP11A were expressed in different subsets of MDMs 

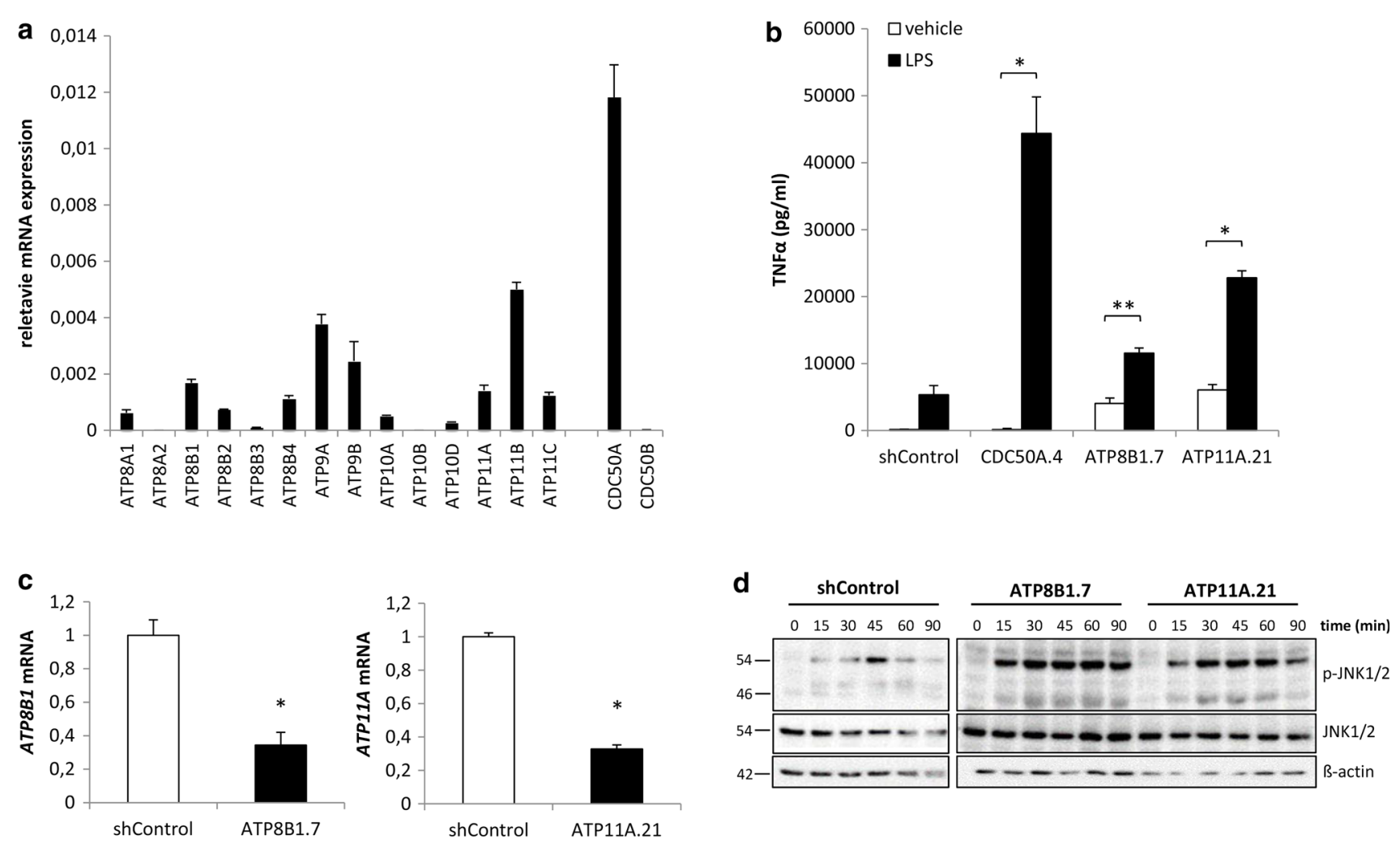

e
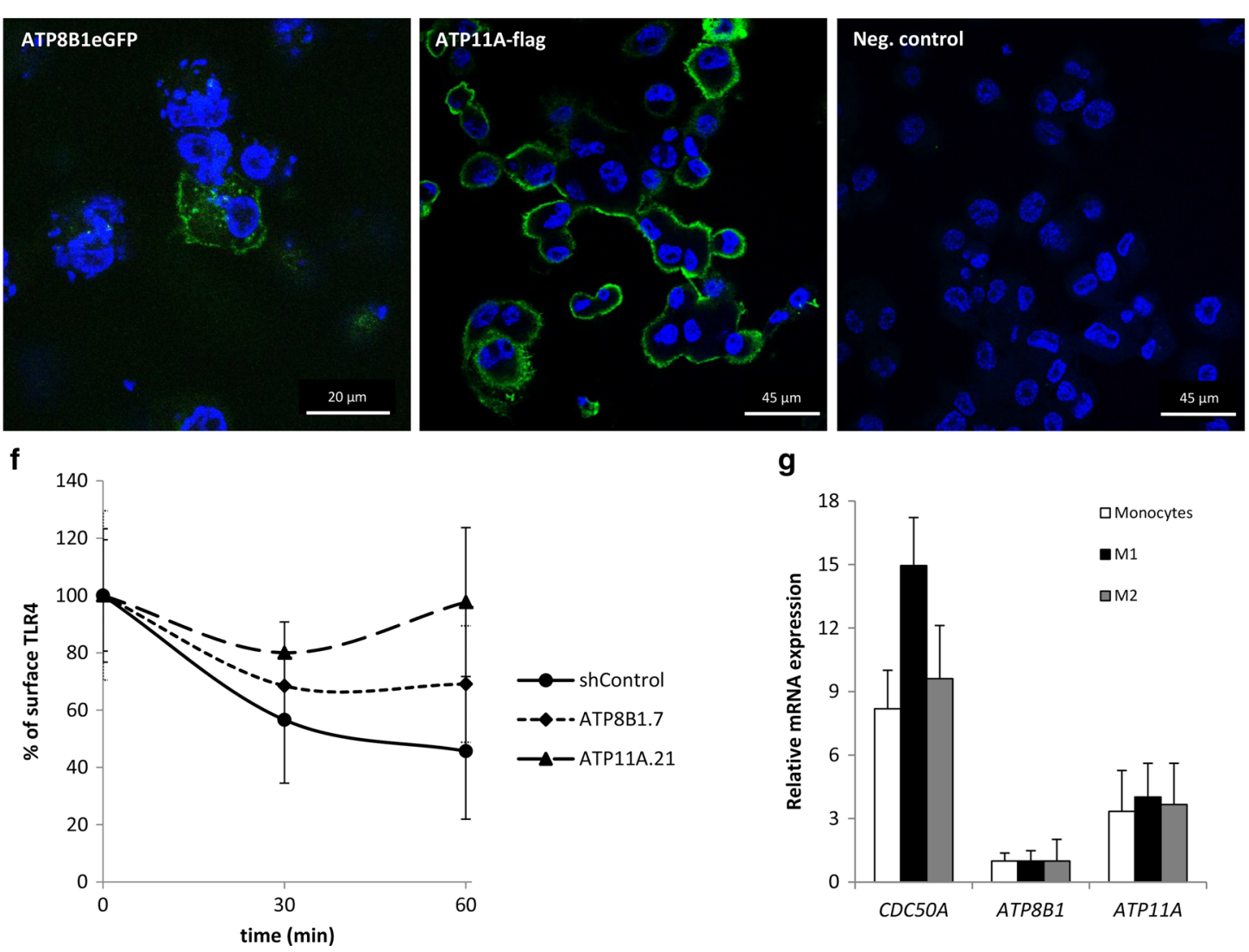
4Fig. 5 ATP8B1 and ATP11A display elevated LPS-induced TLR4mediated signaling and reduced TLR4 internalization. a P4-ATPases, $C D C 50 A$ and $C D C 50 B$ mRNA levels in THP-1 macrophages. mRNA data shown are mean \pm standard deviation of triplicate wells. b TNF $\alpha$ secretion in shControl, CDC50A-, ATP8B1- and ATP11Adepleted THP-1 macrophages $4 \mathrm{~h}$ after $100 \mathrm{ng} / \mathrm{ml}$ LPS administration. Data shown are mean \pm standard deviation of triplicate wells. Statistical significance was tested by one-way ANOVA with Bonferroni's correction for multiple testing, $* p<0.00001, * * p=0.05$. c ATP8B1 and ATP11A mRNA levels in shControl and ATP8B1- andATP11A depleted THP-1 macrophages. Data shown are mean $\pm \mathrm{s}$ tandard deviation of triplicate wells. Statistical significance was tested by a Student's $t$ test, $* p<0.001$. d Immunoblot analysis of activated JNK1/2 in shControl, ATP8B1- and ATP11A-depleted THP-1 macrophages. Cells were incubated with $100 \mathrm{ng} / \mathrm{ml}$ LPS for the time points indicated. $\beta$-Actin is included as a loading control. e Confocal microscopical detection of GFP-tagged ATP8B1 (ATP8B1eGFP) and flag-tagged ATP11A (ATP11A-flag) in THP-1 macrophages. Both ATP8B1eGFP and ATP11A-flag are in green and predominantly localize to the plasma membrane. Nuclear DAPI staining in blue. f TLR4 surface expression in shControl, ATP8B1- and ATP11Adepleted THP-1 macrophages after stimulation with $100 \mathrm{ng} / \mathrm{ml}$ LPS. Cells were analyzed and data expressed as described in Fig. 4a. No statistical differences by one-way ANOVA. g CDC50A, ATP8B1 and ATP11A mRNA levels in primary human monocytes and M1- and M2-primed macrophages. Data shown are mean \pm standard deviation of quadruple wells. ATP8B1 expression in the three subsets was set as 1. Data shown in this figure are representative of two to three independent experiments with similar results

(Fig. 5g). These data suggest that ATP8B1 and/or ATP11A are involved in the LPS-induced internalization of TLR4 upon an LPS insult in human macrophages.

\section{CDC50A is involved in endotoxin tolerance in THP-1 macrophages}

Because CDC50A-depleted macrophages displayed a hyper-inflammatory response to LPS, we investigated whether CDC50A could play a role in endotoxin tolerance. CDC50A-depleted THP-1 macrophages were stimulated for $18 \mathrm{~h}$ with $100 \mathrm{ng} / \mathrm{ml} \mathrm{LPS}$, washed and re-stimulated with $100 \mathrm{ng} / \mathrm{ml}$ LPS for $6 \mathrm{~h}$ and TNF $\alpha$ output and TLR4 expression were quantified. TNF $\alpha$ levels in the culture medium of LPS-stimulated, tolerized CDC50A.4 macrophages were $\sim 8$ times higher compared to those in LPSstimulated tolerized shControl cells, indicating a problem with tolerization in CDC50A.4 cells (Fig. 6a). Endotoxin tolerance has been reported to be associated with reduced LPS-induced TLR4-mediated MAPK signaling in mouse macrophages [40], but also with prolonged down-regulation of TLR4 in murine and THP-1 macrophages [41, 42]. $\mathrm{We}$, therefore, assessed the activation of JNK1/2 after restimulation of LPS-tolerized THP-1 cells. ShControl and CDC50A.4 cells were pretreated for $24 \mathrm{~h}$ with medium or $100 \mathrm{ng} / \mathrm{ml}$ LPS after which the cells were washed and restimulated with $100 \mathrm{ng} / \mathrm{ml}$ LPS for the indicated time periods. In LPS-pretreated shControl cells, we could not detect any increase in the phosphorylation status of JNK $1 / 2$ up to 120 min of LPS restimulation, which indicates that these cells were tolerant to LPS (Fig. 6b). In LPS pretreated CDC50A.4 cells, however, phosphorylated JNK1/2 was observed already $30 \mathrm{~min}$ after LPS restimulation indicating loss of endotoxin tolerization in these cells. Total protein levels of TLR4 were greatly reduced in tolerized shControl cells, however, in CDC50A.4 cells TLR4 expression was unaltered (Fig. 6c, quantified in Fig. 6d). These data suggest that CDC50A.4 macrophages display impaired endotoxin tolerance, which is possibly caused by sustained TLR4-mediated signaling.

\section{Discussion}

Here we report in human THP-1 and human primary monocyte-derived macrophages that CDC50A-interacting P4-ATPase are essential to attenuate endotoxin-induced TLR4-mediated signaling possibly by facilitating the endocytic retrieval of TLR4. Endocytosis of TLR4 is not only crucial to prevent severe chronic inflammatory conditions such as sepsis, but also to guarantee a sustained immune response to suppress an ongoing infection. It is well documented that activation of TLR4 sequentially induces two signaling pathways leading to an early and a late inflammatory response [1]. The early response, activated by ligand binding and dimerization of TLR4, initiates signaling via NF- $\kappa \mathrm{B}$ and the MAP kinase (MAPK) pathway and leads to the production of pro-inflammatory cytokines. Our data show that depletion of CDC50A, which is an essential subunit of P4-ATPase phospholipid flippase complexes that localize to (amongst others) the plasma membrane [27-30], results in a hyperactivation of the early response pathway as evidenced by elevated TNF $\alpha, \mathrm{IL}-1 \beta$ and IL6 release, enhanced MAPK signaling and sustained NF- $\kappa \mathrm{B}$ activation. The late response is activated upon ligand-induced TLR4 endocytosis and leads to a type I interferon response $[4,5,7,43]$. We show here that in CDC50A-depleted cells the LPS-induced internalization of TLR4 is impaired and that the induction of the interferon response in these cells is reduced; The lack of complete ablation of the interferon response in our study can be explained by residual expression of CDC50A in the knockdown cells and/or the timing of LPS treatment ( $3 \mathrm{~h}$ in our study).

Collectively, our data suggest that LPS-induced hyperactivation of Myd88-dependent signaling in CDC50Adepleted cells is caused by impaired endocytic retrieval of TLR4 leading to sustained TLR4 signaling. This hypothesis is supported by previous studies in CD14-deficient mouse bone marrow-derived macrophages (BMDM), CD14 being crucial for LPS-induced endocytic retrieval of 


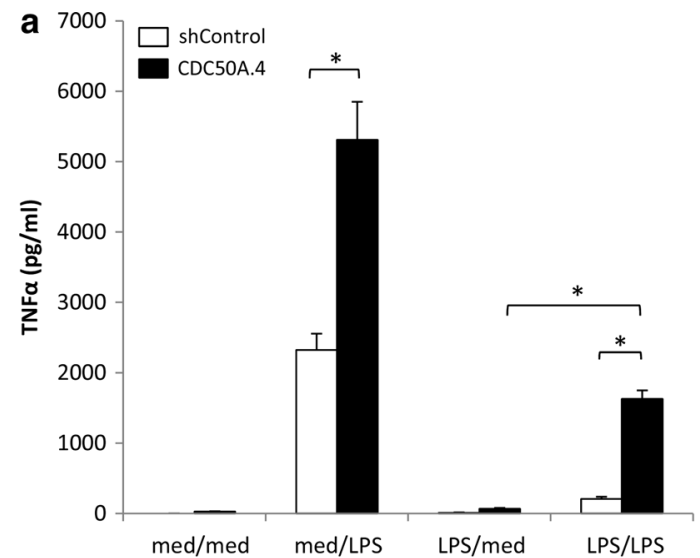

c
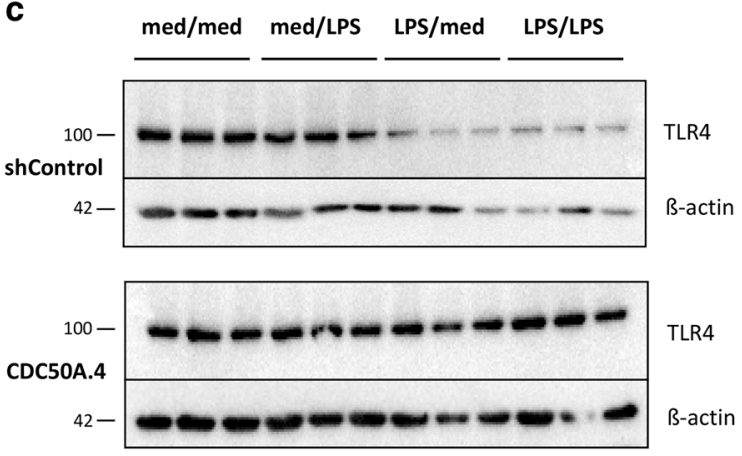

Fig. 6 CDC50A-depleted THP-1 macrophages display a partial loss of endotoxin tolerance. a TNF $\alpha$ secretion in LPS-tolerized and nontolerized shControl and CDC50A-depleted THP-1 macrophages. Cells were incubated with or without $100 \mathrm{ng} / \mathrm{ml}$ LPS for $18 \mathrm{~h}$, washed and re-incubated with or without $100 \mathrm{ng} / \mathrm{ml}$ LPS for $6 \mathrm{~h}$ after which $\mathrm{TNF} \alpha$ secretion was measured. Data shown are mean \pm standard deviation of triplicate wells. Statistical significance was tested by one-way ANOVA with Bonferroni's correction for multiple testing, ${ }^{*} p<0.00005$, med medium. b LPS induced phosphorylation of JNK1/2 in tolerized and non-tolerized shControl and CDC50Adepleted THP-1 macrophages. Cells were incubated with $100 \mathrm{ng} / \mathrm{ml}$ LPS for the time points indicated and cell lysates were analysed for p-JNK1/2 expression by immunoblotting. $\beta$-Actin is included as a

TLR4 [5, 9]. In CD14-deficient BMDMs, TNFa excretion was almost completely abolished at low dose LPS (10 ng/ $\mathrm{ml})$, however, at higher LPS doses $(\geq 100 \mathrm{ng} / \mathrm{ml}) \mathrm{TNF} \alpha$ excretion was increased compared to wild type cells, an observation that remained unexplained [5, 9], but that may be caused by sustained TLR4 signaling. In our study we also applied $100 \mathrm{ng} / \mathrm{ml}$ LPS, which resulted in increased cytokine excretion by CDC50A-depleted cells. We can, however, not exclude that the phenotype in CDC50A-depleted macrophages is caused by two independent processes, i.e., impaired TLR4 internalization and sustained activation of the signaling cascade downstream TLR4. This is underscored by the unexpected observation that inhibition of LPS-induced TLR4 internalization by the dynamin inhibitor dynasore completely abrogated IL6
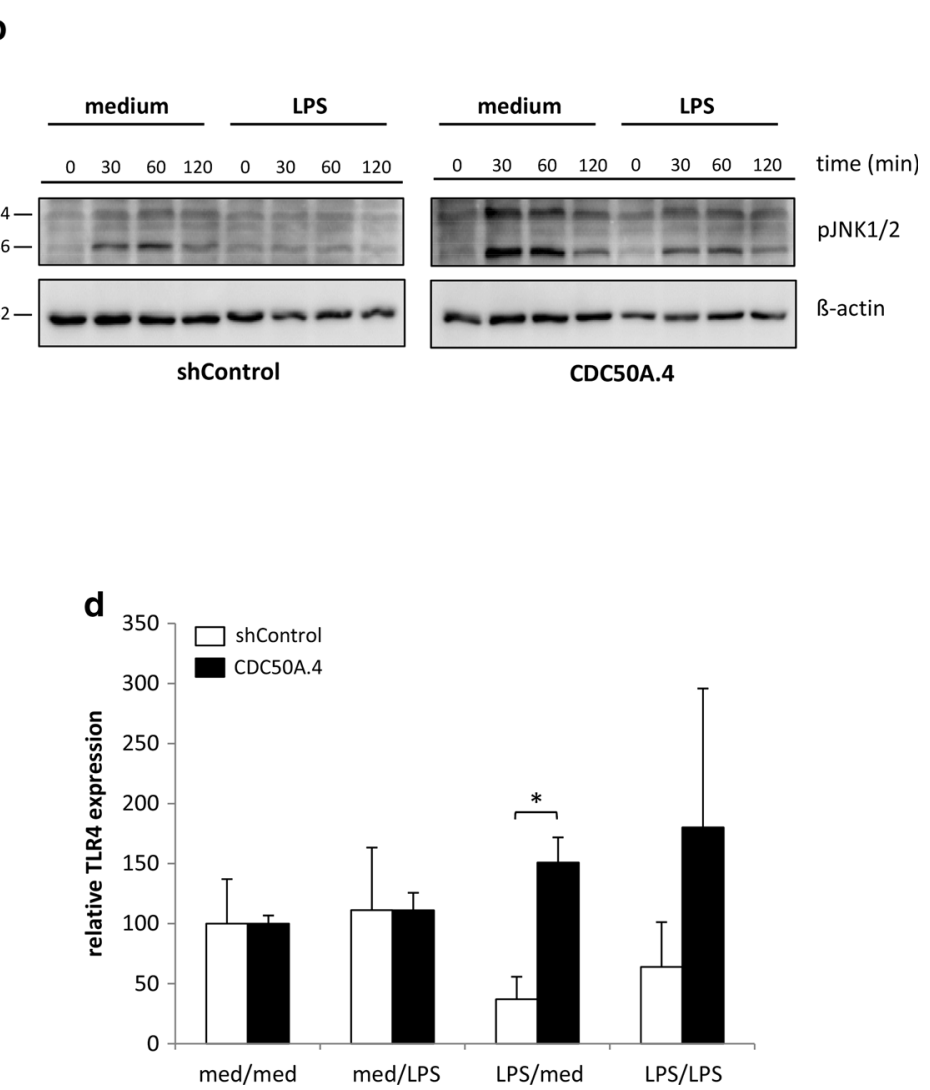

loading control. c TLR4 expression in LPS-tolerized and nontolerized shControl and CDC50A-depleted THP-1 macrophages. Cell lysates were harvested from cells treated as described in Fig. 3a and were analyzed for TLR4 expression by immunoblotting. $\beta$-Actin is included as a loading control. d Quantification of total TLR4 expression in tolerized and non-tolerized shControl and CDC50Adepleted THP-1 macrophages as represented in Fig. 3c. Protein levels were quantified by densitometric analysis, normalized to $\beta$-actin, and expressed as mean percentage \pm standard deviation of protein present in the $\mathrm{med} / \mathrm{med}$ group (set to $100 \%$ ). Statistical significance was tested by a Student's $t$ test, ${ }^{*} p<0.005$. Data shown in Fig. 3 are representative of two independent experiments with similar results

excretion and mRNA expression in CDC50A-depleted macrophages. This observation suggests that the hyper-responsiveness of CDC50A-depleted cells to LPS was not caused by impaired TLR4 internalization. However, the specificity of dynasore, i.e., a selective inhibitor of the dynamin GTPase activity to inhibit clathrin-mediated endocytosis, has recently being disputed [44]. Multiple dynamin-independent effects of dynasore have been described, including disruption of lipid rafts i.e., detergentresistant membrane domains that serve as signaling platforms $[45,46]$. Previous studies have shown that following LPS stimulation, TLR4 and CD14 are mobilized to lipid rafts, an event crucial for TLR4 dimerization and subsequent recruitment and assembly of adaptor proteins; The use of lipid raft-disrupting compounds abrogates the LPS- 
induced TLR4 signaling $[47,48]$. Thus, dynasore treatment of macrophages may not only inhibit clathrin-mediated endocytosis of TLR4 but also the lipid raft-associated TLR4 signaling cascade, explaining the lack of inflammatory reaction in dynasore-treated CDC50A-depleted cells. Still, we cannot exclude the possibility that, apart from blocking TLR4 endocytosis, CDC50A depletion may interfere with Myd88-dependent signaling downstream of TLR4.

We showed that CDC50A-depleted macrophages were impaired in the LPS-induced internalization of TLR4, however, in the TLR4 endocytosis assay TLR4 surface expression was increased 30 and 60 min after LPS challenge compared to unchallenged cells. Although we have no clear explanation for this observation it may be that LPS challenge mobilizes an existing pool of TLR4 to the plasma membrane that subsequently cannot be internalized leading to an increase of TLR4 surface expression post-LPS challenge. Furthermore, and despite increased TLR4 surface expression, TLR4 mRNA levels were reduced in CDC50A-depleted cells, which may be due to the sustained activation of the Myd88-dependent signaling pathway leading to a compensatory down-regulation of TLR4 transcription. Previous studies showed that LPSinduced internalization of TLR4 associates with endocytosis of CD14 [5, 49], although Rajaiah et al. [9] recently reported CD14-independent TLR4 endocytosis. We did not observe any reduction in CD14 surface expression in LPS-challenged control macrophages. Still, CD14 surface expression in CDC50A-depleted cells was strongly increased compared to control cells. An explanation for this observation may be that, due to reduced TLR4 turnover, the cell responds by elevating $C D 14$ transcription with consequent elevation of CD14 surface levels. Indeed, we found that $C D 14$ mRNA levels were increased in CDC50-depleted cells.

CDC50A-depleted cells also displayed a partial loss of endotoxin tolerance. Endotoxin tolerance is a condition of reduced responsiveness to LPS upon a secondary LPS challenge with concomitant repression of proinflammatory cytokine production [50]. Tolerization, which is crucial for dampening a recurrent inflammatory insult and protects the host to fatal infection (i.e, during sceptic shock), is associated with repression of TLR4-mediated signaling and reduced TLR4 surface expression [40-42, 50]. Reduced endotoxin tolerance in CDC50A-depleted cells coincided with enhanced JNK1/2 activation and TNF $\alpha$ excretion upon restimulation with LPS. Furthermore, whereas in control cells total TLR4 protein levels were reduced after overnight LPS challenge, TLR4 protein levels were unaffected in CDC50A-depleted cells. Apparently, sustained TLR4 surface expression accounts for the reduced tolerized state in CDC50A-depleted cells.
CDC50A-depleted cells were phenocopied by ATP8B1and ATP11A-depleted cells with regard to enhanced LPSinduced $\mathrm{JNK} 1 / 2$ activation, $\mathrm{TNF} \alpha$ output and impaired LPS-induced internalization of TLR4. This underscores the need for obligate heterodimerization of a member of the P4-ATPase family of phospholipid flippases with CDC50A to form an active phospholipid flippase complex. These phenotypes were, however, not as dramatic as in CDC50Adepleted cells, which can be best explained by residual activity of these P4-ATPases or activity of other, redundant P4-ATPases.

How are P4-ATPases involved in the endocytic retrieval of TLR4? Although CDC50A was detected in intracellular vesicles, both ATP8B1 and ATP11A predominantly localized to the plasma membrane of THP-1 cells, which renders a role in the endocytic retrieval, recycling and/or TGN-to plasma membrane delivery likely. One of the preferred canonical substrates for ATP8B1 and ATP11A is phosphatidylserine (PS) [12, 27, 51], although recently phosphatidylcholine (PC) has been proposed to be a substrate for ATP8B1 as well [51]. PS has been implicated to drive endocytic processes in human and yeast cells [52-54]; for instance, Farge et al. have shown that the formation of endocytic vesicles was enhanced when the cytosolic surface area was expanded upon incubation of the cells with PS and PE analogs, a process that depended on a plasma membrane flippase activity [52]. P4-ATPases can catalyze a local concentration of phospholipids and the consequential vesiculation according to the bilayer couple hypothesis [55]. This hypothesis proposes that if one leaflet of a bilayer expands through a local increase in phospholipids, the coupled leaflet follows, which leads to bending of the bilayer. The resulting membrane curvature facilitates binding of curvature-stabilizing proteins and/or proteins of the vesicle-generating machinery. For instance, F-BAR domain-containing proteins sense and stabilize shallow membrane curvatures in the early steps of membrane invagination and contain positively charged membrane binding domains that interact with PS [56-58]. In addition, the negative charge of the serine head group in PS is important for recruiting positively charged proteins of the vesicle-generating machinery to initiation sites within the endocytic pathway [59]. Such a mechanism has recently been confirmed by Xu et al. [60] who showed that localized PS flipping by the $S$. cerevisiae P4-ATPase Drs2p creates a negatively charged, curved membrane structure that recruits the ADP-ribosylation factor GTPase activating protein (ARF-GAP) Gcs1, a major regulator of the vesiclegenerating machinery [61]. In addition, Lui et al. previously demonstrated an essential role for the PS flippase Drs2p in the formation of clathrin-coated vesicles at the TGN [62]. Very recently Bruurs et al. have shown that ATP8B1 is essential for clustering of $\mathrm{Cdc} 42$, which can 
interact with PS [63], during the establishment of the apical membrane of enterocytes [64]. Based on these observations, we hypothesize that ATP8B1 and/or ATP11A mediate local clustering of PS or other phospholipids at the plasma membrane to induce a curvature which facilitates the binding of proteins of the vesicle-generating machinery, including clathrin. This is the initiating event in the biogenesis of clathrin-coated pits via which LPS-ligated TLR4 is endocytosed. Indeed, Husebye et al. previously reported that endocytosis of TLR4 relies on clathrin [4].

Here we report an essential role for CDC50A-associated phospholipid flippases in the innate immune response. Although it remains to be determined how these proteins are involved in the inflammatory reaction and what the relative contribution is to this process, we have identified two potential candidates i.e., ATP8B1 and ATP11A, both of which are expressed in human macrophages. Deficiency of ATP8B1 or ATP11A is associated with chronic inflammatory conditions in humans. For instance, patients with ATP8B1 deficiency present with severe chronic liver disease but are also susceptible to pneumonia [65, 66]. Previously, it was proposed that pulmonary infection in ATP8B1 deficiency causes pulmonary cardiolipin levels to rise leading to impaired lung (surfactant) function, leading to pulmonary inflammation, a hypothesis that was debated by us $[67,68]$. Based on our present work, an alternative explanation can be that patients have problems attenuating the TLR4-mediated inflammatory reaction in pulmonary macrophages. Similarly, in a recent genome-wide association study ATP11A was associated with fibrotic idiopathic interstitial pneumonias, a group of pulmonary disorders associated with inflammation and fibrosis [69]. Whether P4-ATPase genes are novel risk genes for inflammatory disease remains to be established.

Acknowledgments We thank Drs. L. W. Klomp and J. B. Koenderink for polyclonal antibodies to ATP8B1 and ATP1A1, respectively, and Drs. B. C. Tilly and H. R. de Jonge for the Rab11eGFP plasmid.

Open Access This article is distributed under the terms of the Creative Commons Attribution 4.0 International License (http:// creativecommons.org/licenses/by/4.0/), which permits unrestricted use, distribution, and reproduction in any medium, provided you give appropriate credit to the original author(s) and the source, provide a link to the Creative Commons license, and indicate if changes were made.

\section{References}

1. Kawai T, Akira S (2010) The role of pattern-recognition receptors in innate immunity: update on Toll-like receptors. Nat Immunol 11(5):373-384. doi:10.1038/ni.1863
2. Poltorak A, Ricciardi-Castagnoli P, Citterio S, Beutler B (2000) Physical contact between lipopolysaccharide and toll-like receptor 4 revealed by genetic complementation. Proc Natl Acad Sci USA 97(5):2163-2167. doi:10.1073/pnas.040565397

3. Lee CC, Avalos AM, Ploegh HL (2012) Accessory molecules for Toll-like receptors and their function. Nat Rev Immunol 12(3):168-179. doi:10.1038/nri3151

4. Husebye H, Halaas O, Stenmark H, Tunheim G, Sandanger O, Bogen B, Brech A, Latz E, Espevik T (2006) Endocytic pathways regulate Toll-like receptor 4 signaling and link innate and adaptive immunity. EMBO J 25(4):683-692. doi:10.1038/sj.emboj. 7600991

5. Zanoni I, Ostuni R, Marek LR, Barresi S, Barbalat R, Barton GM, Granucci F, Kagan JC (2011) CD14 controls the LPS-induced endocytosis of Toll-like receptor 4. Cell 147(4):868-880. doi:10. 1016/j.cell.2011.09.051

6. Jiang Z, Georgel P, Du X, Shamel L, Sovath S, Mudd S, Huber M, Kalis C, Keck S, Galanos C, Freudenberg M, Beutler B (2005) CD14 is required for MyD88-independent LPS signaling. Nat Immunol 6(6):565-570. doi:10.1038/ni1207

7. Kagan JC, Su T, Horng T, Chow A, Akira S, Medzhitov R (2008) TRAM couples endocytosis of Toll-like receptor 4 to the induction of interferon-beta. Nat Immunol 9(4):361-368. doi:10. 1038/ni1569

8. Lucas K, Maes M (2013) Role of the Toll Like receptor (TLR) radical cycle in chronic inflammation: possible treatments targeting the TLR4 pathway. Mol Neurobiol 48(1):190-204. doi:10. 1007/s12035-013-8425-7

9. Rajaiah R, Perkins DJ, Ireland DD, Vogel SN (2015) CD14 dependence of TLR4 endocytosis and TRIF signaling displays ligand specificity and is dissociable in endotoxin tolerance. Proc Natl Acad Sci USA 112(27):8391-8396. doi:10.1073/pnas. 1424980112

10. Sebastian TT, Baldridge RD, Xu P, Graham TR (2012) Phospholipid flippases: building asymmetric membranes and transport vesicles. Biochim Biophys Acta 1821(8):1068-1077. doi:10. 1016/j.bbalip.2011.12.007

11. van der Mark VA, Elferink RP, Paulusma CC (2013) P4 ATPases: flippases in health and disease. Int $\mathrm{J}$ Mol Sci 14(4):7897-7922. doi:10.3390/ijms14047897

12. Lopez-Marques RL, Theorin L, Palmgren MG, Pomorski TG (2014) P4-ATPases: lipid flippases in cell membranes. Pflugers Arch 466(7):1227-1240. doi:10.1007/s00424-013-1363-4

13. Holthuis JC, Menon AK (2014) Lipid landscapes and pipelines in membrane homeostasis. Nature 510(7503):48-57. doi:10.1038/ nature 13474

14. Pomorski T, Lombardi R, Riezman H, Devaux PF, van Meer G, Holthuis JC (2003) Drs2p-related P-type ATPases Dnf1p and Dnf2p are required for phospholipid translocation across the yeast plasma membrane and serve a role in endocytosis. Mol Biol Cell 14(3):1240-1254. doi:10.1091/mbc.E02-08-0501

15. Gall WE, Geething NC, Hua Z, Ingram MF, Liu K, Chen SI, Graham TR (2002) Drs2p-dependent formation of exocytic clathrin-coated vesicles in vivo. Curr Biol 12(18):1623-1627

16. Hua Z, Fatheddin P, Graham TR (2002) An essential subfamily of Drs2p-related P-type ATPases is required for protein trafficking between Golgi complex and endosomal/vacuolar system. Mol Biol Cell 13(9):3162-3177. doi:10.1091/mbc.E02-03-0172

17. Ruaud AF, Nilsson L, Richard F, Larsen MK, Bessereau JL, Tuck S (2009) The $C$. elegans P4-ATPase TAT-1 regulates lysosome biogenesis and endocytosis. Traffic 10(1):88-100. doi:10.1111/j. 1600-0854.2008.00844.X

18. Chen B, Jiang Y, Zeng S, Yan J, Li X, Zhang Y, Zou W, Wang X (2010) Endocytic sorting and recycling require membrane phosphatidylserine asymmetry maintained by TAT-1/CHAT-1. PLoS Genet 6(12):e1001235. doi:10.1371/journal.pgen.1001235 
19. Poulsen LR, Lopez-Marques RL, McDowell SC, Okkeri J, Licht D, Schulz A, Pomorski T, Harper JF, Palmgren MG (2008) The Arabidopsis P4-ATPase ALA3 localizes to the golgi and requires a beta-subunit to function in lipid translocation and secretory vesicle formation. Plant Cell 20(3):658-676. doi:10.1105/tpc. 107.054767

20. Moreno-Smith M, Halder JB, Meltzer PS, Gonda TA, Mangala LS, Rupaimoole R, Lu C, Nagaraja AS, Gharpure KM, Kang Y, Rodriguez-Aguayo C, Vivas-Mejia PE, Zand B, Schmandt R, Wang H, Langley RR, Jennings NB, Ivan C, Coffin JE, Armaiz GN, Bottsford-Miller J, Kim SB, Halleck MS, Hendrix MJ, Bornman W, Bar-Eli M, Lee JS, Siddik ZH, Lopez-Berestein G, Sood AK (2013) ATP11B mediates platinum resistance in ovarian cancer. J Clin Invest 123(5):2119-2130. doi:10.1172/ JCI65425

21. van der Mark VA, de Waart DR, Ho-Mok KS, Tabbers MM, Voogt HW, Oude Elferink RP, Knisely AS (1842) Paulusma CC (2014) The lipid flippase heterodimer ATP8B1-CDC50A is essential for surface expression of the apical sodium-dependent bile acid transporter (SLC10A2/ASBT) in intestinal Caco-2 cells. Biochim Biophys Acta 12 Pt A:2378-2386. doi:10.1016/j.bbadis. 2014.09.003

22. Lee S, Uchida Y, Wang J, Matsudaira T, Nakagawa T, Kishimoto T, Mukai K, Inaba T, Kobayashi T, Molday RS, Taguchi T, Arai $H$ (2015) Transport through recycling endosomes requires EHD1 recruitment by a phosphatidylserine translocase. EMBO J 34(5):669-688. doi:10.15252/embj.201489703

23. Bull LN, van Eijk MJ, Pawlikowska L, DeYoung JA, Juijn JA, Liao M, Klomp LW, Lomri N, Berger R, Scharschmidt BF, Knisely AS, Houwen RH, Freimer NB (1998) A gene encoding a P-type ATPase mutated in two forms of hereditary cholestasis. Nat Genet 18(3):219-224. doi:10.1038/ng0398-219

24. Onat OE, Gulsuner S, Bilguvar K, Nazli Basak A, Topaloglu H, Tan M, Tan U, Gunel M, Ozcelik T (2013) Missense mutation in the ATPase, aminophospholipid transporter protein ATP8A2 is associated with cerebellar atrophy and quadrupedal locomotion. Eur J Hum Genet 21(3):281-285. doi:10.1038/ejhg.2012.170

25. Katoh Y, Katoh M (2004) Identification and characterization of CDC50A, CDC50B and CDC50C genes in silico. Oncol Rep 12(4):939-943

26. Folmer DE, Mok KS, de Wee SW, Duijst S, Hiralall JK, Seppen J, Oude Elferink RP, Paulusma CC (2012) Cellular localization and biochemical analysis of mammalian CDC50A, a glycosylated beta-subunit for P4 ATPases. J Histochem Cytochem 60(3):205-218. doi:10.1369/0022155411435705

27. Paulusma CC, Folmer DE, Ho-Mok KS, de Waart DR, Hilarius PM, Verhoeven AJ, Oude Elferink RP (2008) ATP8B1 requires an accessory protein for endoplasmic reticulum exit and plasma membrane lipid flippase activity. Hepatology 47(1):268-278. doi:10.1002/hep. 21950

28. van der Velden LM, Wichers CG, van Breevoort AE, Coleman JA, Molday RS, Berger R, Klomp LW, van de Graaf SF (2010) Heteromeric interactions required for abundance and subcellular localization of human CDC50 proteins and class 1 P4-ATPases. J Biol Chem 285(51):40088-40096. doi:10.1074/jbc.M110. 139006

29. Bryde S, Hennrich H, Verhulst PM, Devaux PF, Lenoir G, Holthuis JC (2010) CDC50 proteins are critical components of the human class-1 P4-ATPase transport machinery. J Biol Chem 285(52):40562-40572. doi:10.1074/jbc.M110.139543

30. Takatsu H, Baba K, Shima T, Umino H, Kato U, Umeda M, Nakayama K, Shin HW (2011) ATP9B, a P4-ATPase (a putative aminophospholipid translocase), localizes to the trans-Golgi network in a CDC50 protein-independent manner. J Biol Chem 286(44):38159-38167. doi:10.1074/jbc.M111.281006
31. Seppen J, Rijnberg M, Cooreman MP, Oude Elferink RP (2002) Lentiviral vectors for efficient transduction of isolated primary quiescent hepatocytes. J Hepatol 36(4):459-465

32. Choudhury A, Dominguez M, Puri V, Sharma DK, Narita K, Wheatley CL, Marks DL, Pagano RE (2002) Rab proteins mediate Golgi transport of caveola-internalized glycosphingolipids and correct lipid trafficking in Niemann-Pick C cells. J Clin Invest 109(12):1541-1550. doi:10.1172/JCI15420

33. Daigneault M, Preston JA, Marriott HM, Whyte MK, Dockrell DH (2010) The identification of markers of macrophage differentiation in PMA-stimulated THP-1 cells and monocyte-derived macrophages. PLoS One 5(1):e8668. doi:10.1371/journal.pone. 0008668

34. Ruijter JM, Ramakers C, Hoogaars WM, Karlen Y, Bakker O, van den Hoff MJ, Moorman AF (2009) Amplification efficiency: linking baseline and bias in the analysis of quantitative PCR data. Nucleic Acids Res 37(6):e45. doi:10.1093/nar/gkp045

35. Vandesompele J, De Preter K, Pattyn F, Poppe B, Van Roy N, De Paepe A, Speleman F (2002) Accurate normalization of real-time quantitative RT-PCR data by geometric averaging of multiple internal control genes. Genome Biol 3(7):RESEARCH0034

36. Pawlikowska L, Groen A, Eppens EF, Kunne C, Ottenhoff R, Looije N, Knisely AS, Killeen NP, Bull LN, Elferink RP, Freimer NB (2004) A mouse genetic model for familial cholestasis caused by ATP8B1 mutations reveals perturbed bile salt homeostasis but no impairment in bile secretion. Hum Mol Genet 13(8):881-892. doi: $10.1093 / \mathrm{hmg} / \mathrm{ddh} 100$

37. Koenderink JB, Geibel S, Grabsch E, De Pont JJ, Bamberg E, Friedrich T (2003) Electrophysiological analysis of the mutated $\mathrm{Na}$, K-ATPase cation binding pocket. J Biol Chem 278(51):51213-51222. doi:10.1074/jbc.M306384200

38. Jaguin M, Houlbert N, Fardel O, Lecureur V (2013) Polarization profiles of human M-CSF-generated macrophages and comparison of M1-markers in classically activated macrophages from GM-CSF and M-CSF origin. Cell Immunol 281(1):51-61. doi:10. 1016/j.cellimm.2013.01.010

39. Mansell A, Smith R, Doyle SL, Gray P, Fenner JE, Crack PJ, Nicholson SE, Hilton DJ, O'Neill LA, Hertzog PJ (2006) Suppressor of cytokine signaling 1 negatively regulates Toll-like receptor signaling by mediating Mal degradation. Nat Immunol 7(2):148-155. doi:10.1038/ni1299

40. Medvedev AE, Kopydlowski KM, Vogel SN (2000) Inhibition of lipopolysaccharide-induced signal transduction in endotoxin-tolerized mouse macrophages: dysregulation of cytokine, chemokine, and toll-like receptor 2 and 4 gene expression. J Immunol 164(11):5564-5574

41. Nomura F, Akashi S, Sakao Y, Sato S, Kawai T, Matsumoto M, Nakanishi K, Kimoto M, Miyake K, Takeda K, Akira S (2000) Cutting edge: endotoxin tolerance in mouse peritoneal macrophages correlates with down-regulation of surface toll-like receptor 4 expression. J Immunol 164(7):3476-3479

42. Martin M, Katz J, Vogel SN, Michalek SM (2001) Differential induction of endotoxin tolerance by lipopolysaccharides derived from Porphyromonas gingivalis and Escherichia coli. J Immunol 167(9):5278-5285

43. Yamamoto M, Sato S, Hemmi H, Uematsu S, Hoshino K, Kaisho T, Takeuchi O, Takeda K, Akira S (2003) TRAM is specifically involved in the Toll-like receptor 4-mediated MyD88-independent signaling pathway. Nat Immunol 4(11):1144-1150. doi:10. 1038/ni986

44. Preta G, Cronin JG, Sheldon IM (2015) Dynasore-not just a dynamin inhibitor. Cell Commun Signal 13:24. doi:10.1186/ s12964-015-0102-1

45. Preta G, Lotti V, Cronin JG, Sheldon IM (2015) Protective role of the dynamin inhibitor Dynasore against the cholesterol-dependent 
cytolysin of Trueperella pyogenes. FASEB J 29(4):1516-1528. doi:10.1096/fj.14-265207

46. Plociennikowska A, Hromada-Judycka A, Borzecka K, Kwiatkowska K (2015) Co-operation of TLR4 and raft proteins in LPSinduced pro-inflammatory signaling. Cell Mol Life Sci 72(3):557-581. doi:10.1007/s00018-014-1762-5

47. Triantafilou M, Miyake K, Golenbock DT, Triantafilou K (2002) Mediators of innate immune recognition of bacteria concentrate in lipid rafts and facilitate lipopolysaccharide-induced cell activation. J Cell Sci 115(Pt 12):2603-2611

48. Pfeiffer A, Bottcher A, Orso E, Kapinsky M, Nagy P, Bodnar A, Spreitzer I, Liebisch G, Drobnik W, Gempel K, Horn M, Holmer S, Hartung T, Multhoff G, Schutz G, Schindler H, Ulmer AJ, Heine H, Stelter F, Schutt C, Rothe G, Szollosi J, Damjanovich S, Schmitz G (2001) Lipopolysaccharide and ceramide docking to CD14 provokes ligand-specific receptor clustering in rafts. Eur J Immunol 31(11):3153-3164. doi:10.1002/1521-4141(200111)31: $11<3153$ :aid-immu3153>3.0.co;2-0

49. Klein DC, Skjesol A, Kers-Rebel ED, Sherstova T, Sporsheim B, Egeberg KW, Stokke BT, Espevik T, Husebye H (2015) CD14, TLR4 and TRAM show different trafficking dynamics during LPS stimulation. Traffic. doi:10.1111/tra.12274

50. Biswas SK, Lopez-Collazo E (2009) Endotoxin tolerance: new mechanisms, molecules and clinical significance. Trends Immunol 30(10):475-487. doi:10.1016/j.it.2009.07.009

51. Takatsu H, Tanaka G, Segawa K, Suzuki J, Nagata S, Nakayama K, Shin HW (2014) Phospholipid flippase activities and substrate specificities of human type IV P-type ATPases localized to the plasma membrane. J Biol Chem 289(48):33543-33556. doi:10. 1074/jbc.M114.593012

52. Farge E, Ojcius DM, Subtil A, Dautry-Varsat A (1999) Enhancement of endocytosis due to aminophospholipid transport across the plasma membrane of living cells. Am J Physiol 276(3 Pt 1):C725-C733

53. Sun Y, Drubin DG (2012) The functions of anionic phospholipids during clathrin-mediated endocytosis site initiation and vesicle formation. J Cell Sci 125(Pt 24):6157-6165. doi:10.1242/jcs.115741

54. Zha X, Genest J Jr, McPherson R (2001) Endocytosis is enhanced in Tangier fibroblasts: possible role of ATP-binding cassette protein A1 in endosomal vesicular transport. J Biol Chem 276(42):39476-39483. doi:10.1074/jbc.M105067200

55. Sheetz MP, Singer SJ (1974) Biological membranes as bilayer couples. A molecular mechanism of drug-erythrocyte interactions. Proc Natl Acad Sci USA 71(11):4457-4461

56. Coutinho-Budd J, Ghukasyan V, Zylka MJ, Polleux F (2012) The F-BAR domains from srGAP1, srGAP2 and srGAP3 regulate membrane deformation differently. $\mathrm{J}$ Cell Sci $125(\mathrm{Pt}$ 14):3390-3401. doi:10.1242/jcs.098962

57. Uezu A, Umeda K, Tsujita $K$, Suetsugu $S$, Takenawa $T$, Nakanishi H (2011) Characterization of the EFC/F-BAR domain protein, FCHO2. Genes Cells 16(8):868-878. doi:10.1111/j.13652443.2011.01536.X

58. Rao Y, Haucke V (2011) Membrane shaping by the Bin/amphiphysin/Rvs (BAR) domain protein superfamily. Cell Mol Life Sci 68(24):3983-3993. doi:10.1007/s00018-011-0768-5

59. Yeung T, Gilbert GE, Shi J, Silvius J, Kapus A, Grinstein S (2008) Membrane phosphatidylserine regulates surface charge and protein localization. Science 319(5860):210-213. doi:10. 1126/science. 1152066
60. Xu P, Baldridge RD, Chi RJ, Burd CG, Graham TR (2013) Phosphatidylserine flipping enhances membrane curvature and negative charge required for vesicular transport. J Cell Biol 202(6):875-886. doi:10.1083/jcb.201305094

61. Cherfils J, Zeghouf M (2013) Regulation of small GTPases by GEFs, GAPs, and GDIs. Physiol Rev 93(1):269-309. doi:10. 1152/physrev.00003.2012

62. Liu K, Surendhran K, Nothwehr SF, Graham TR (2008) P4ATPase requirement for AP-1/clathrin function in protein transport from the trans-Golgi network and early endosomes. Mol Biol Cell 19(8):3526-3535. doi:10.1091/mbc.E08-01-0025

63. Fairn GD, Hermansson M, Somerharju P, Grinstein S (2011) Phosphatidylserine is polarized and required for proper $\mathrm{Cdc} 42$ localization and for development of cell polarity. Nat Cell Biol 13(12):1424-1430. doi:10.1038/ncb2351

64. Bruurs LJ, Donker L, Zwakenberg S, Zwartkruis FJ, Begthel H, Knisely AS, Posthuma G, van de Graaf SF, Paulusma CC, Bos JL (2015) ATP8B1-mediated spatial organization of Cdc42 signaling maintains singularity during enterocyte polarization. J Cell Biol 210(7):1055-1063. doi:10.1083/jcb.201505118

65. Pawlikowska L, Strautnieks S, Jankowska I, Czubkowski P, Emerick K, Antoniou A, Wanty C, Fischler B, Jacquemin E, Wali S, Blanchard S, Nielsen IM, Bourke B, McQuaid S, Lacaille F, Byrne JA, van Eerde AM, Kolho KL, Klomp L, Houwen R, Bacchetti P, Lobritto S, Hupertz V, McClean P, Mieli-Vergani G, Shneider B, Nemeth A, Sokal E, Freimer NB, Knisely AS, Rosenthal P, Whitington PF, Pawlowska J, Thompson RJ, Bull LN (2010) Differences in presentation and progression between severe FIC1 and BSEP deficiencies. J Hepatol 53(1):170-178. doi:10.1016/j.jhep.2010.01.034

66. Whitington PF, Freese DK, Alonso EM, Schwarzenberg SJ, Sharp HL (1994) Clinical and biochemical findings in progressive familial intrahepatic cholestasis. J Pediatr Gastroenterol Nutr 18(2):134-141

67. Ray NB, Durairaj L, Chen BB, McVerry BJ, Ryan AJ, Donahoe M, Waltenbaugh AK, O'Donnell CP, Henderson FC, Etscheidt CA, McCoy DM, Agassandian M, Hayes-Rowan EC, Coon TA, Butler PL, Gakhar L, Mathur SN, Sieren JC, Tyurina YY, Kagan VE, McLennan G, Mallampalli RK (2010) Dynamic regulation of cardiolipin by the lipid pump Atp8b1 determines the severity of lung injury in experimental pneumonia. Nat Med 16(10):1120-1127. doi:10.1038/nm.2213

68. Paulusma CC, Houwen RH, Williamson PL (2011) The flip side of cardiolipin import. Nat Med 17(4):413. doi:10.1038/nm0411413a author reply $\mathbf{4 1 3}-\mathbf{4 1 4}$

69. Fingerlin TE, Murphy E, Zhang W, Peljto AL, Brown KK, Steele MP, Loyd JE, Cosgrove GP, Lynch D, Groshong S, Collard HR, Wolters PJ, Bradford WZ, Kossen K, Seiwert SD, du Bois RM, Garcia CK, Devine MS, Gudmundsson G, Isaksson HJ, Kaminski N, Zhang Y, Gibson KF, Lancaster LH, Cogan JD, Mason WR, Maher TM, Molyneaux PL, Wells AU, Moffatt MF, Selman M, Pardo A, Kim DS, Crapo JD, Make BJ, Regan EA, Walek DS, Daniel JJ, Kamatani Y, Zelenika D, Smith K, McKean D, Pedersen BS, Talbert J, Kidd RN, Markin CR, Beckman KB, Lathrop M, Schwarz MI, Schwartz DA (2013) Genome-wide association study identifies multiple susceptibility loci for pulmonary fibrosis. Nat Genet 45(6):613-620. doi:10.1038/ng.2609 